\title{
Changes in the content and intensity of oxidation of lipid compounds in the kidneys of lambs fed diets with rapeseed and fish oils - effect of antioxidant supplementation
}

\author{
M. Białek ${ }^{1}$, M. Czauderna ${ }^{1,3}$, K. Zaworski' ${ }^{1}$ M. Karpińska ${ }^{1}$ and M. Marounek ${ }^{2}$ \\ ${ }^{1}$ The Kielanowski Institute of Animal Physiology and Nutrition, Polish Academy of Sciences, 05-110 Jabłonna, Poland \\ ${ }^{2}$ Institute of Animal Science, Department of Nutrition Physiology and Animal Product Quality, \\ CZ-104 00, Praha-Uhřiněves, Czech Republic
}

KEY WORDS: carnosic acid, cholesterol, fatty acids, malondialdehyde, selenium, sheep, tocopherols

Received: 29 March 2021

Revised: 20 June 2021

Accepted: 12 July 2021
${ }^{3}$ Corresponding author:

e-mail: m.czauderna@ifzz.pl

\begin{abstract}
The aim of this study was to investigate the effects of supplementation of diets containing rapeseed (R-O) and fish ( $\mathrm{F}-\mathrm{O}$ ) oils with carnosic acid (C-A) and Se (as Se-enriched yeast (Se-Y) or selenate (Se-VI)) on concentrations of fatty acids (FAs), tocopherols, cholesterol and malondialdehyde (MDA) in lamb kidneys. Male Corriedale lambs with average body weight $(23.3 \pm 2.1 \mathrm{~kg})$ and age (82-90 days) were individually penned, and divided into 4 groups, 6 animals each. After the 3-week preliminary period, the 35-day dietary experiment was conducted with the following experimental design: 1) control diet - basal diet (BD) with 2\% R-O and 1\% F-O; 2) CA diet - BD with $2 \%$ R-O, $1 \%$ F-O and $0.1 \%$ C-A; 3) CA-SeY diet - BD with 2\% R-O, 1\% F-O, 0.1\% C-A and $0.35 \mathrm{mg}$ Se (as Se-Y)/kg BD; and 4) CA-SeVI diet - BD with 2\% R-O, 1\% F-O, $0.1 \% \mathrm{C}-\mathrm{A}$ and $0.35 \mathrm{mg}$ Se (as Se-VI)/kg BD. Feeding lambs with the CA-SeVI diet increased $(P \leq 0.05)$ the live weight, kidneys weight and feed conversion efficiency when compared to lambs fed CA and CA-SeY diets. The CA-SeY diet decreased $(P \leq 0.05)$ the concentration of the sum of FAs in the kidneys compared to the control and CA-SeVI diets. The experimental diets reduced $(P \leq 0.05)$ the level of $n-3$ polyunsaturated FAs (PUFAs), long-chain PUFAs (LPUFAs) and the hypocholesterolemic/hypercholesterolemic FAs ratio compared to the control diet. The experimental diets enriched with Se-Y or Se-VI reduced $(P \leq 0.05)$ the concentration of MDA in the kidneys compared to the control and CA diets. The experimental diet containing only $\mathrm{C}$-A stimulated $(P \leq 0.05)$ the oxidative degradation of PUFAs as compared to the control and other experimental diets. The modified atherogenic index was used to evaluate atherogenic properties in the kidneys. The obtained results help to understand the potential beneficial impact of C-A, $\mathrm{Se}-\mathrm{Y}$ and $\mathrm{Se}-\mathrm{VI}$ supplements in diets with $\mathrm{F}-\mathrm{O}$ (rich in LPUFAs) on the lipid content and oxidative parameters in lamb kidneys. The investigation provides also new practical knowledge for nutritionists carrying out further studies aimed at improving farm animal health, growth performance and welfare of lambs.
\end{abstract}

\section{Introduction}

Selenium (Se), an essential micronutrient in the diet of mammals, plays an important role in the physiology, behaviour, health and reproduction of farm animals (Juniper et al., 2008; Ibrahim et al., 2020; Mikulková et al., 2020). In molecules of enzymes and proteins, Se usually occurs in the form of seleno-cysteine (Se-Cys) and seleno-methionine (Se-Met). Se-enzymes, ubiquitous in mammal 
organisms, play there an important role (Schweizer et al., 2005; Juniper et al., 2008). These Seenzymes protect cell biomolecules and components (essential long-chain polyunsaturated fatty acids (LPUFAs), enzymes, proteins, DNA and cell membranes) against oxidation. In the antioxidant enzymes, like glutathione peroxidases, glycine reductases, tetraiodothyronine 5'-deiodinases, thioredoxin reductases, methionine-R-sulphoxide reductase B1, seleno-phosphate synthetase 2, formate dehydrogenases and some hydrogenases, mainly Se-Cys is incorporated. Se-Cys is co-translationally incorporated into the growing polypeptide chain in response to an inframe UGA codon (Schweizer et al., 2005). In mammals, the presence of a specific RNA stem-loop structure in the 3'-untranslated region of the mRNA recodes the opal STOP codon to dictate Se-Cys incorporation (Schweizer et al., 2005). Moreover, Seenzymes, by reducing the peroxide tone of intracellular water, inhibit pro-inflammatory cell metabolisms (suppression of nuclear factor kappa-light-chainenhancer of activated B cells (NF- $\mathrm{B}$ ) pathway, arachidonic acid pathway and complement cascades, and attenuation of mitochondrial dysfunction) (AlBasher et al., 2020; Shi et al., 2020) and thus, may improve immunological functions in the organism. Taking all these reasons into account an adequate dietary supplementation of essential trace elements (like Se), fatty acids (FAs) and antioxidants seems to be of utmost importance from the physiological point of view (Attia et al., 2018; Uhlíŕová and Volek, 2019; Wei et al., 2020). Because of very low levels of Se in feedstuffs, a way to meet nutritional requirements in terms of Se content may be a diet supplementation. According to National Research Council (NRC, 2007), the required content of $\mathrm{Se}$ in lamb diets is $\sim 0.3 \mathrm{ppm}$; interestingly, the maximum tolerable level of Se in lamb diets is 2 ppm. On the other hand, higher contents of Se in diets, more precisely 7-10 ppm, can be toxic for sheep as well as other ruminants (McDowell et al., 2005; Navarro-Alarcon and Cabrera-Vique, 2008). In the dietary supplements, Se is usually present in two forms: inorganic chemical form (like selenate or selenite) and organic form of Se such as Se-enriched yeast (Se-Y), in which Se-Met is the predominant chemical form of Se (Czauderna et al., 2009c).

In addition to Se, polyunsaturated fatty acids (PUFAs) found in some vegetable oils have received considerable interest, since they have beneficial health effects (Fernández et al., 2007; Haliga et al., 2015). The recent studies documented that especially dietary long-chain n-3PUFAs (n-3LPUFAs) found in fish oil (F-O) play an important role in cardiovascular disease prevention and may lead to beneficial changes in the blood FAs profile in consumers of animal products enriched in n-3LPUFAs. Recently, an effort has been made to improve the composition of FAs profile in farm animal products, especially by the modification of feeding ration. The composition of FAs in meat and milk can be changed by including various, vegetable oils, F-O or other animal fats into animal diets. In fact, dietary vegetable oils, F-O, different chemical forms of Se and herbal nutraceuticals (like carnosic acid (C-A)) affect production parameters (feed intake, feed conversion efficiency (FCE), live weight gain) and the growth or/and activity of ruminal microbes in lambs (Czauderna et al., 2017). Unfortunately, an increase in highly unsaturated long-chain FAs (LHPUFAs) levels in animal carcasses was followed by an increase in the concentrations of lipid oxidation products and cholesterol oxidation products (Lagarde et al., 2018). The extent of lipid oxidation depends on several factors, including the content of unsaturated fatty acids (UFAs) as well as antioxidants (like Se-compounds, C-A or tocopherols) (Afonso et al., 2013; Mikulková et al., 2020; Tuoxunjiang et al., 2020). Recent studies have shown that feeding diets enriched in Se-Y (rich in Se-Met) to animals results in effective biosynthesis of antioxidant enzymes, indicating that the animal organism converts Se-Met derived from Se-Y to Se-Cys, which is an essential amino acid for the biosynthesis of antioxidant Se-enzymes (Juniper et al., 2008; Czauderna et al., 2017). In fact, it has been found that Se-Y and selenate (Se-VI) added to the diet enriched in C-A, F-O (rich in LHPUFAs) and rapeseed oil (R-O) (rich in n-6PUFAs) affected the concentrations of saturated fatty acids (SFAs), monounsaturated fatty acids (MUFAs), PUFAs, cholesterol, tocopherols and the yield of lipid peroxidation in the liver, brain, heart, muscles and adipose tissues of lambs (Białek et al., 2018; Czauderna et al., 2018; Białek and Czauderna, 2019). Interestingly, during the Se supplementation in ruminants, the effect of enrichment on the Se level in internal organs and muscles is different (Czauderna et al., 2017; 2018). Kidneys are organs that store the highest amount of Se followed by the liver, testis and lungs (Czauderna and Smogorzewska, 1986). Se-Met was the predominant Se-amino acid within the kidney (54 to 60\% of total Se), irrespective of the chemical form of Se in animal diets (Juniper et al., 2008). The previous studies showed that Se supplementations could protect against acute kidney injury development via antioxidant, anti-apoptotic and anti-inflamma- 
tory activities (Shanu et al., 2013; AlBasher et al., 2020). Indeed, antioxidant intervention (like Se supplementation) is effective against acute kidney injury associated with excessive production of free radicals by suppressing the lipid peroxidation of the proximal tubular cells and myoglobin metabolism. Moreover, dietary Se caused an increase in kidney weight and affected the lipid profile in kidneys (AlBasher et al., 2020). On the other hand, a highfat diet and hyperlipidemia are serious risk factors of chronic kidney disease (Gai et al., 2019). In fact, kidneys from animals fed a high-fat diet were characterized by chronic inflammation, high concentrations of reactive oxygen species, excess of oxidized high-density lipoprotein cholesterol (HDL-C), renal tubular damage and fibrosis in the glomeruli. Therefore, it may be presumed that the lipid profile of kidneys may be influenced not only by the Se but also by lipid compounds present in the diet.

As we have presented in our previous studies, diets enriched in Se-Y or Se-VI stimulated concentrations of Se in lamb tissues such as heart, muscles or whole blood (Czauderna et al., 2017; 2018). Considering the above, we hypothesized that Se-compounds added to the diet enriched in F-O, R-O and C-A would affect also concentrations of FAs, tocopherols, cholesterol and oxidative stress in lamb kidneys. It was also expected that these modifications depend upon the chemical form of dietary Se (i.e. Se-Y and Se-VI). Moreover, we supposed that dietary C-A and Se-compounds (as Se-Y and Se-VI) will not cause visual macroscopic lesions and visual toxic symptoms in lambs fed diets rich in PUFAs. Thus, the main aim of our study was to investigate the impact of the different chemical forms of $\mathrm{Se}$ (as $\mathrm{Se}-\mathrm{Y}$ or $\mathrm{Se}-\mathrm{VI}$ ) added to the diet containing $\mathrm{C}-\mathrm{A}, \mathrm{R}-\mathrm{O}$ and odourless F-O on concentrations of selected FAs (particularly LHPUFAs), tocopherols, total cholesterol (T-Ch) and malondialdehyde (MDA; a marker of lipid peroxidation (Czauderna et al., 2011b)) in lamb kidneys.

\section{Material and methods}

\section{Animals, experimental design, diets and management}

Twenty four male Corriedale lambs were selected from a herd of lambs ( 110 male lambs) according to their similar body weight (BW) (23.3 \pm $2.1 \mathrm{~kg}$ ) and age (82-90 days). All experiments on the animals were carried out at The Kielanowski Institute of Animal Physiology and Nutrition, Polish Academy of Sciences (PAS) (Jabłonna,
Poland). Lamb welfare guidelines and handling procedures recommended by the Third Local Commission of Animal Experiment Ethics at the Warsaw University of Life Sciences (Warsaw, Poland) (the approval number: 41/2013) were strictly followed throughout the preliminary and experimental period. During a 3-week preliminary period the animals were individually penned; the width, length and height of the pen were $(\mathrm{cm}) 130$, 170 and 150, respectively. All lambs were fed basal diet (BD) which was enriched in R-O and F-O (i.e. the control diet). The lambs were given free access to the diet; water was offered ad libitum. The BD consisted of the following ingredients: meadow hay $(360 \mathrm{~g} / \mathrm{kg})$, a mixture of soyabean $(360 \mathrm{~g} / \mathrm{kg})$ and barley $(165 \mathrm{~g} / \mathrm{kg})$ meals, wheat starch $(90 \mathrm{~g} / \mathrm{kg})$ and the mineral-vitamin mixture $(20 \mathrm{~g} / \mathrm{kg})$. Feed analyses were conducted in The Kielanowski Institute of Animal Physiology and Nutrition, PAS (Jabłonna, Poland) using AOAC International (2005) methods. The chemical composition of the $\mathrm{BD}$ and its ingredients is presented in Table 1. After a 3-week preliminary period, lambs with an average $\mathrm{BW}$ of $30.4 \pm 2.6 \mathrm{~kg}$ were divided into 4 groups of 6 lambs each. The animals were distributed into 4 groups according to the initial weights so that the average initial body weights of lambs between the groups were similar. Next, the 35-day dietary experiment $(4 \times 1$ factorial experimental design $)$ was conducted with the following design: 1) control diet - basal diet (BD) with $2 \%$ R-O and $1 \%$ F-O; 2) $\mathrm{CA}$ diet - BD with $2 \% \mathrm{R}-\mathrm{O}, 1 \% \mathrm{~F}-\mathrm{O}$ and $0.1 \%$ C-A; 3) CA-SeY diet - BD with $2 \%$ R-O, $1 \% \mathrm{~F}-\mathrm{O}, 0.1 \% \mathrm{C}-\mathrm{A}$ and $0.35 \mathrm{mg}$ Se (as Se-Y) $/ \mathrm{kg}$ $\mathrm{BD}$; and 4) CA-SeVI diet - BD with $2 \%$ R-O, $1 \%$ F-O, $0.1 \%$ C-A and $0.35 \mathrm{mg} \mathrm{Se}$ (as Se-VI) $/ \mathrm{kg} \mathrm{BD}$ (Table 2). The control and three experimental diets were administrated to animals twice a day $(7: 30$ and 16:00) in equal amounts; drinking water was available ad libitum. The control and experimental diets were formulated to be iso-energetic and isoproteinous; the amounts of all diets were weekly adjusted to both the body weight of animals and their nutritional requirements according to Strzetelski et al. (2014); there were no feed refusals. The average daily dietary intake was $1.08 \mathrm{~kg}$ per lamb; during the 35-day experiment, each lamb consumed $37.8 \mathrm{~kg}$ of the control or experimental diets. At the end of the experimental period, all animals were deprived of consciousness by the intramuscular injections of xylazine (2-4 mg per $10 \mathrm{~kg}$ of BW) and then slaughtered. The lambs were slaughtered in accordance with the European Union Council (EC) 
Table 1. Chemical composition of the basal diet $(\mathrm{BD})$ and its ingredients (the concentrate-hay diet with vitamins and mineral mixture ${ }^{1}$ ) (AOAC International, 2015)

\begin{tabular}{|c|c|c|c|c|c|}
\hline \multicolumn{6}{|c|}{ Chemical composition of the BD ingredients ${ }^{2,3}, \%$ of dry matter (DM) } \\
\hline \multirow{2}{*}{ Indices } & \multirow{2}{*}{ Meadow hay ${ }^{5}$} & & \multicolumn{3}{|l|}{ Concentrate $^{6}$} \\
\hline & & & barley meal & soybean meal & wheat starch \\
\hline Dry matter, \% BD & 88.4 & & 87.6 & 89.7 & 87.3 \\
\hline Crude protein & 9.50 & & 9.94 & 41.81 & 0.90 \\
\hline Crude fibre & 27.29 & & 2.87 & 4.34 & - \\
\hline Crude fat & 3.40 & & 2.50 & 2.25 & 0.09 \\
\hline Ash & 4.85 & & 1.84 & 6.16 & 0.12 \\
\hline Neutral detergent fibre & 59.17 & & 18.02 & 18.81 & - \\
\hline Acid detergent fibre & 32.08 & & 4.61 & 6.44 & - \\
\hline Acid detergent lignin & 4.47 & & 1.14 & 1.49 & - \\
\hline Se content, mg Se/kg & 0.003 & & 0.016 & 0.020 & -4 \\
\hline \multicolumn{6}{|l|}{ Chemical composition of the BD } \\
\hline Indices & & Amount & & & \\
\hline Dry matter, g/kg BD & & 884.3 & & & \\
\hline Crude protein, g/kg DM & & 201.9 & & & \\
\hline Crude fibre, g/kg DM & & 118.6 & & & \\
\hline Crude fat ${ }^{7}, \mathrm{~g} / \mathrm{kg} \mathrm{BD}$ & & 21.7 & & & \\
\hline Total crude fat ${ }^{8}, \mathrm{~g} / \mathrm{kg} \mathrm{BD}$ & & 51.7 & & & \\
\hline Ash, g/kg DM & & 42.8 & & & \\
\hline Neutral detergent fibre, $\mathrm{g} / \mathrm{kg}$ DM & & 310.5 & & & \\
\hline Acid detergent fibre, g/kg DM & & 146.3 & & & \\
\hline Acid detergent lignin, $\mathrm{g} / \mathrm{kg}$ DM & & 23.3 & & & \\
\hline Gross energy ${ }^{9}, \mathrm{MJ} / \mathrm{kg} \mathrm{DM}$ & & 17.9 & & & \\
\hline Se concentration, mg Se/kg BD & & 0.16 & & & \\
\hline
\end{tabular}

${ }^{1}$ one $\mathrm{kg}$ of the $\mathrm{BD}$ contained $20 \mathrm{~g}$ of the mineral and vitamin mixture (premix); one $\mathrm{kg}$ of the mineral and vitamin mixture comprised: $\mathrm{g}$ : Ca 285, P 16, Na 56, Fe 1 (as sulphate), Cu 0.5 (as sulphate), Mn 5.8 (as sulphate), Zn 7.5 (as sulphate); mg: Co 42 (as carbonate), I 10 (as iodate), Se 6 (as sodium selenite); IU: vit. A 500 000, vit. D 125000 and vit. E 25000 (as a-tocopherol); ${ }^{2}$ the gross energy (MJ/kg of DM): meadow hay 17.1 , barley meal 16.3 , soyabean meal 17.8 , wheat starch $16.7 ;{ }^{3}$ the contents of toxic elements in the BD: $\mathrm{mg} / \mathrm{kg}:$ As $1.39 \pm 0.03$, $\mathrm{Cd} 0.068 \pm 0.001$, Sb $0.0155 \pm 0.0015$ and Pb $0.514 \pm 0.003 ;{ }^{4}$ the Se content in wheat starch was below the detection limit; ${ }^{5}$ main fatty acids (FAs) content in the meadow hay: mg/kg: C8:0 83, C12:0 142, C14:0 239, c9C15:1 131, C16:0 4034, c9C16:1 184, C18:0 459, c9C18:1 1266, c12C18:1 72, c9c12C18:2 (LA) 13100, c9c12c15C18:3 (aLNA) 4178, C20:0 58, c11C20:1 74, C22:0 101, C24:0 69, c15C24:1 71; ${ }^{6}$ main FAs content in concentrate: mg/kg: C14:0 104, C16:0 3189, C18:0 1425, c9C18:1 774, LA 29163, aLNA 1014; ${ }^{7}$ crude fat originating from BD (i.e. the meadow hay and concentrate); ${ }^{8}$ total crude fat originating from the $\mathrm{BD}$ and added oils (i.e. rapeseed oil (R-O) and fish oil (F-O)); ${ }^{9}$ total gross energy of the BD enriched in R-O and F-O without or with antioxidant(s) (i.e. C-A, Se as Se-enriched yeast (Se-Y) or Se-VI (Se as selenate))

Regulations No 1099/2009 dated 24.09.2009 for the protection of animals at the time of slaughter in small experimental slaughterhouses. The effects of the control and experimental diets on all internal organs, muscles and adipose tissues of slaughtered lambs were visually evaluated by professional veterinary staff. Immediately after slaughtering, two kidneys were removed from each lamb; approximately the average weight of extracted two kidneys from each lamb was $\sim 130 \mathrm{~g}$. Then, two kidneys from each lamb were homogenized. Homogenized kidney samples were stored in sealed tubes at $-32{ }^{\circ} \mathrm{C}$ until further analytical analyses. Concentrations of FAs, tocopherols, T-Ch and MDA in the kidney samples were expressed from fresh matter.

\section{Chemicals and reagents}

Methanol, n-hexane and acetonitrile of HPLCgrade were purchased from a Lab-Scan (Dublin, Ireland). A mixture of conjugated linoleic acid
(CLA) isomers and other 37 fatty acid standard mixture (FAME), sodium selenate (Se-VI), $\alpha$-tocopherol, $\alpha$-tocopheryl acetate, cholesterol, sorbic acid, 2,6-ditert-butyl-p-cresol, $25 \%$ aqueous 1,5-pentanedialdehyde solution, 2,4-dinitrophenylhydrazine, 1,1,3,3-tetramethoxy-propane $(99 \%)$ and trichloroacetic acid, $25 \% \mathrm{BF}_{3}$ in methanol were provided by SigmaAldrich (St. Louis, MO, USA). Dichloromethane, $\mathrm{KOH}, \mathrm{NaOH}$ and $\mathrm{HCl}$ were purchased from Avantor Performance Materials (Gliwice, Poland). Other chemicals were of analytical grade. The highly-selenized yeast (Se-Y; selenized Saccharomyces cerevisiae) was obtained from Sel-Plex (Alltech, Nicholasville, KY, USA). Approximately $83 \%$ of the total Se-content of the Se-Y is in the form of Se-Met; $5 \%$ of $\mathrm{Se}$ is in the form of Se-Cys incorporated into the proteins of selenized-Saccharomyces cerevisiae (Rozbicka-Wieczorek et al., 2016a). C-A was obtained from Hunan Geneham Biomedical Technology Ltd. (Changsha, Hunan, China). The vitamin and mineral 
mixture Polfamix O-K was purchased from Trouw Nutrition Polska Sp. z o. o. (Grodzisk Mazowiecki, Poland). R-O and odourless F-O were supplied by Company AGSOL (Pacanów, Poland). The energy content of F-O and R-O was 36.8 and $37.0 \mathrm{MJ} / \mathrm{kg}$ oil, respectively. Odourless F-O contained the following main FA (mg/kg F-O): C12:0 82, C14:0 12345, cis9C14:1 215, C15:0 477, C16:0 56947, c7C16:1 318, c9C16:1 420, $\Sigma \mathrm{C} 16: 2$ 15586, C17:0 493, c9C17:1 193, C18:0 9452, c6C18:1 188, c7C18:1 842, c9C18:1 290592, c12C18:1 15834, $c 14 \mathrm{C} 18: 1159, c 9 c 12 \mathrm{C} 18: 2$ (LA) $114512, c 9 c-$ 12c15C18:2 (aLNA) 20968, c11C20:1 24206, c7c9c12c15C18:4 473, c11c14C20:2 2270, c8c11c14C20:3 258, c5c8c11c14C20:4 (AA) 304, c8c11c14c17C20:4 607, C22:0 139, c13C22:1 11036, c11C22:1 1704, c5c8c11c14c17C20:5 (EPA) 6792, c13c16C22:2 95, c7c10c13c16C22:4 144, c15C24:1 397, c7c10c13c16c19C22:5 (DPA) 1560 and $c 4 c 7 c 10 c 13 c 16 c 19 \mathrm{C} 22: 5$ (DHA) 26570. R-O comprised the following main FAs (mg/kg R-O): C14:0 56, C16:0 13091, c9C16:1 33, C18:0 5490, c9C18:1 385859, c12C18:1 786, LA 282394, $\alpha$ LNA 38474, C20:0 194, c11C20:1 108, C22:0 430 and c15C24:161.

\section{Analytical methods and chromatographic equipment}

Homogenized kidney samples $(50-70 \mathrm{mg})$ were saponificated using $\mathrm{KOH}$ solutions according to methods previously described by Czauderna et al. (2009a). Then, base- and acid-catalysed methylations were introduced for the preparation of methyl esters of FAs (FAME) in processed kidney samples (Czauderna et al., 2009a). FAME in biological samples were then quantified using gas chromatography (GC) with mass spectrometry (MS) according to methods previously described by Czauderna et al. (2009a). The FAME analyses were performed on a gas chromatograph GC-MSQP2010 Plus EI (Shimadzu, Tokyo, Japan) equipped with quadrupole mass selective detector (Model 5973N; Shimadzu, Tokyo, Japan), BPX70 fused silica column $(120 \mathrm{~m} \times 0.25 \mathrm{~mm}$ i.d. $\times 0.25 \mu \mathrm{m}$ film thickness; Phenomenex, Torrance, CA, USA) and an injection port. FAME identification was validated based on electron impact ionization spectra of FAME and compared to authentic FAME standards and the NIST 2007 reference mass spectra library. All FAME analyses performed on the kidney samples were based on total ion current chromatograms and/ or selected-ion monitoring chromatograms.

The tocopherols and $\mathrm{T}$-Ch were quantified in kidney samples using a reversed-phase liquid chromatographic system according to methods described by Czauderna et al. (2009b). The used liquid chromatographic instrument (Shimadzu, Tokyo, Japan) consisted of ultra-fast liquid chromatography (UFLC-DAD) system, incorporating two LC-20ADXP pumps, SIL-20ACXR autosampler, CBM-20A communications bus module, CTO-20A column oven, DGU-20A5 degasser and SPD photodiode array detector (DAD) and Kinetex C18-column (particle size $2.6 \mu \mathrm{m}$; Hydro-RP, $150 \mathrm{~mm} \times 2.1 \mathrm{~mm}$ i.d.; Phenomenex, Torrance, $\mathrm{CA}$, USA).

The chromatographic separations of derivatized MDA from endogenic species of the kidney samples were conducted using the above described UFLC-DAD system (Czauderna et al., 2011b), but with C18-column (Synergi, Hydro-RP, particle size $2.5 \mu \mathrm{m}, 100 \AA, 100 \mathrm{~mm} \times$ $2 \mathrm{~mm}$ i.d.; Phenomenex; Torrance, CA, USA). Atherogenic $\left({ }_{\text {index }} \mathrm{A}^{\mathrm{SFA}}\right)$ and thrombogenic $\left({ }_{\text {index }} \mathrm{T}^{\mathrm{SFA}}\right)$ indices were calculated according to the equations given by Morán et al. (2013). The hypocholesterolemic/hypercholesterolemic FAs (h/H-Ch) ratio was calculated using the equation given by Fernández et al. (2007). The modified atherogenic index $\left({ }_{\text {index }} \mathrm{A}^{\text {SFA+Toc }}\right)$ was calculated in the following manner (Białek et al., 2020):

$$
\begin{aligned}
& { }_{\text {index }} \mathrm{A}^{\mathrm{SFA}+\mathrm{Toc}}={ }_{\text {index }} \mathrm{A}^{\mathrm{SFA}} /\left(1.49 \times \mathrm{C}_{\alpha \mathrm{T}}+1.36 \times \mathrm{C}_{\alpha \mathrm{TAc}}+\right. \\
& \left.0.15 \times \mathrm{C}_{\gamma \mathrm{T}}+0.05 \times \mathrm{C}_{\delta \mathrm{T}}\right) \text {, }
\end{aligned}
$$

where: $\mathrm{C}_{\alpha \mathrm{T}}, \mathrm{C}_{\alpha \mathrm{TAc}}, \mathrm{C}_{\gamma \mathrm{T}}$ and $\mathrm{C}_{\delta \mathrm{T}}$ - concentrations of $\alpha$-tocopherol, $\alpha$-tocopheryl acetate, $\gamma$-tocopherol and $\delta$-tocopherol, respectively; $1.49,1.36,0.15$ and 0.05 are coefficients of biological activity of tocopherols (Zu and Ip, 2003; Rozbicka-Wieczorek et al., 2016a).

\section{Statistical analysis}

All statistical analyses of the effects of dietary additives were carried out using the Statistica 12.5 PL software package (StatSoft Inc., Tulsa, OK, USA). Differences were considered significant at $P \leq 0.05$. The obtained results are shown as means and standard error of means (SEM), except for BW, kidney weight and FCE (mean \pm standard deviation). The influence of dietary modifications on the examined parameters in all kidney samples for variables with normal distribution was tested with one-way ANOVA and the post-hoc Honestly Significant Difference (HSD) Tukey test. For variables without normal distribution, the results were tested with Kruskal-Wallis, which is a nonparametric equivalent of one-way ANOVA, with the post-hoc multiple comparison test. 


\section{Results}

The results of the current investigation showed that R-O (rich in n-6PUFAs), F-O (rich in LHPUFAs), C-A and Se (as Se-Y or Se-VI) supplemented to the diet did not cause harmful symptoms (like diarrhoea and vomiting), as well as no visual changes in the kidneys as well as in the liver, spleen and brain of lambs, were observed. The results summarized in Table 2 showed that the CA-SeVI diet increased $(P \leq 0.05)$ the BW of lambs, kidney weight, the relative weight of kidneys and FCE compared to the CA and CA-SeY diets. atherogenic SFAs (A-SFA) to the concentration of the sum of all assayed FAs ( $\Sigma F A)(\mathrm{A}-\mathrm{SFA} / \Sigma \mathrm{FA})$ in the kidneys in comparison to the control diet. The experimental diet containing C-A and Se-VI decreased $(P \leq 0.05)$ the concentration ratio of $\Sigma$ SFA to the concentration of the sums of UFAs ( $\Sigma$ SFA/ $/ \mathrm{UFA}$ ) and PUFA ( $\Sigma$ SFA/ $/$ PUFA) in the kidneys compared to the control and CA-SeY diet.

\section{Concentrations of MUFAs and PUFAs in the kidneys of lambs}

The effect of the experimental diets on the concentrations of selected MUFAs and values of

Table 2. The experimental scheme, and the body weight (BW) of lambs, kidneys weight, feed conversion efficiency (FCE) and contents of Se in the liver, heart, whole blood and musculus longissimus dorsi (MLD) of lambs fed control and experimental diets

\begin{tabular}{|c|c|c|c|c|c|c|c|c|c|}
\hline \multicolumn{2}{|l|}{ The experimental scheme } & \multicolumn{2}{|l|}{ BW } & Kidneys weight & \multirow{2}{*}{$\begin{array}{c}\mathrm{FCE}^{6} \\
\overline{5} \mathrm{~kg} / \mathrm{kg}\end{array}$} & \multicolumn{4}{|c|}{$\begin{array}{l}\text { Contents of Se in tissues, } \\
\mu \mathrm{g} \mathrm{Se} / \mathrm{g} \text { tissue }\end{array}$} \\
\hline $\operatorname{diets}^{1}$ & $\begin{array}{l}\text { supplements added } \\
\text { to } 1 \mathrm{~kg} \text { of the } \mathrm{BD}\end{array}$ & initial, $\mathrm{kg}^{2}$ & final, $\mathrm{kg}^{3}$ & $\mathrm{~g} / \mathrm{kg} \mathrm{BW}^{5}$ & & liver $^{8}$ & heart $^{8}$ & $\begin{array}{l}\text { whole } \\
\text { blood }^{9}\end{array}$ & $M L D^{2}$ \\
\hline Control (basal diet, BD) & $\begin{array}{l}20 \mathrm{~g} \mathrm{R}-\mathrm{O} \\
10 \mathrm{~g} \mathrm{~F}-\mathrm{O}\end{array}$ & $30.6 \pm 2.4$ & $37.7 \pm 2.1^{\mathrm{ab}}$ & $130 \pm 4^{\mathrm{ab}} 3.44^{\mathrm{b}}$ & $0.189^{\mathrm{ab}}$ & $0.70^{c}$ & $0.80^{\circ}$ & $0.20^{c}$ & $0.25^{c}$ \\
\hline $\mathrm{CA}$ & $\begin{array}{r}20 \text { g R-O } \\
10 \text { g F-O } \\
1 \text { g C-A }\end{array}$ & $30.6 \pm 2.6$ & $37.2 \pm 2.3^{b}$ & $123 \pm 5^{b} 3.30^{b}$ & $0.174^{b}$ & $0.74^{c}$ & $0.87^{b}$ & $0.23^{c}$ & $0.26^{c}$ \\
\hline CA-SeY & $\begin{array}{l}20 \mathrm{~g} \mathrm{R}-\mathrm{O} \\
10 \mathrm{~g} \mathrm{~F}-\mathrm{O} \\
1 \mathrm{~g} \mathrm{C}-\mathrm{A} \\
0.35 \mathrm{mg} \text { Se as Se-Y }\end{array}$ & $30.3 \pm 2.7$ & $36.8 \pm 2.7^{b}$ & $122 \pm 4^{b} 3.32^{b}$ & $0.174^{b}$ & $1.38^{\mathrm{b}}$ & $1.13^{\mathrm{a}}$ & $0.30^{\mathrm{a}}$ & $0.35^{\mathrm{a}}$ \\
\hline CA-SeVI & $\begin{array}{l}20 \mathrm{~g} \mathrm{R} \text { R-O } \\
10 \mathrm{~g} \mathrm{~F}-\mathrm{O} \\
1 \mathrm{~g} \mathrm{C}-\mathrm{A} \\
0.35 \mathrm{mg} \text { Se as Se-VI }\end{array}$ & $30.3 \pm 3.0$ & $38.5 \pm 3.1^{\mathrm{a}}$ & $143 \pm 5^{\mathrm{a}} 3.71^{\mathrm{a}}$ & $0.215^{\mathrm{a}}$ & $1.45^{\mathrm{a}}$ & $1.14^{\mathrm{a}}$ & $0.26^{b}$ & $0.32^{b}$ \\
\hline
\end{tabular}

R-O - rapeseed oil, F-O - fish oil, C-A - carnosic acid, Se-Y - Se-enriched yeast, Se-VI - selenate ; ${ }^{\mathrm{a}-\mathrm{c}}$ - means with different superscripts within a column are significantly different at $P \leq 0.05 ;{ }^{1}$ the Se content in the control, CA, CA-SeY and CA-SeVI diets: $0.16,0.16,0.51$ and $0.51 \mathrm{mg} \mathrm{Se} / \mathrm{kg}$ diet, respectively; ${ }^{2}$ the average initial body weight (mean $\pm \mathrm{SD}$ ) of lambs after the 3-week of the preliminary period; for the 3 -week of preliminary period lambs were fed the control diet; ${ }^{3}$ the average body weight (mean \pm SD) of lambs fed the diets for 35 days of the experimental period; ${ }^{4}$ the weight of two kidneys; ${ }^{5}$ the relative weight of kidneys $(\mathrm{g} / \mathrm{kg})=$ weight of two kidneys $(\mathrm{g}) /$ final BW of lambs $(\mathrm{kg}) ;{ }^{6} \mathrm{FCE}$ for 35 days of the experimental period $=[\mathrm{kg}$ body weight gain $(\mathrm{BWG})] /\left[\mathrm{kg}\right.$ diet intake] where BWG $=$ final $\mathrm{BW}-$ initial $\mathrm{BW} ;{ }^{7}$ concentrations of Se in the liver, heart, whole blood and MLD samples were expressed from fresh matter; ${ }^{8}$ published in Czauderna et al. (2018); ${ }^{9}$ published in Czauderna et al. (2017)

\section{Concentrations of selected saturated fatty acids (SFAs) in the kidneys of lambs}

The current study demonstrated that the experimental diets enriched with either F-O, C-A, Se-VI or Se-Y affect the concentration of selected SFAs in the kidneys of lambs (Table 3). All experimental diets decreased $(P \leq 0.05)$ the concentrations of $\mathrm{C10}$ :0, $\mathrm{C} 17: 0$ and $\mathrm{C} 22: 0$ in the kidneys when compared to lambs fed the control diet. Similarly, the experimental diet containing C-A, irrespectively of the presence of Se-Y, decreased the concentration of the sum of all assayed SFAs ( $\Sigma$ SFA) in the kidneys compared to the control diet. On the other hand, all experimental diets increased $(P \leq 0.05)$ the concentration ratio of indices of desaturation of unsaturated fatty acids are shown in Table 4. The concentrations of $c 7 \mathrm{C} 16: 1$ and $c 9 \mathrm{C} 16: 1$ were lower $(P \leq 0.05)$ in the kidneys of lambs fed experimental diets compared to the control diet. Similarly, the CA and CA-SeY diets reduced $(P \leq 0.05)$ the concentration of $c 12 \mathrm{C} 18: 1$ in the kidneys in comparison with the control and CA-SeVI diets. The CA and CA-SeVI diets increased $(P \leq 0.05)$ values of the $\Delta 9$-desaturation of C18:0 index ( $\left.{ }^{\mathrm{C} 18: 1} \Delta 9_{\text {index }}\right)$ in the kidneys compared to the control and CA-SeY diets. Similarly, the CA and CA-SeVI diets increased $(P \leq 0.05)$ values of total desaturations of unsaturated FA index $\left(\Sigma \Delta 9,5,4-\mathrm{FA}_{\text {index }}\right)$ in the kidneys in comparison 
Table 3. The concentrations ( $\mathrm{mg} / 100 \mathrm{~g}$ kidneys) of selected individual saturated fatty acids (SFAs), atherogenic-SFAs (A-SFA) ${ }^{1}$, thrombogenic-

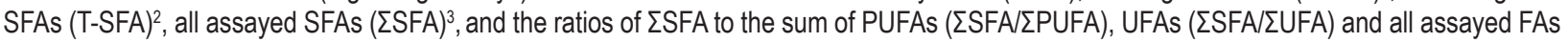
( $\Sigma S F A / \Sigma F A)$ in the kidneys of lambs fed control and experimental diets

\begin{tabular}{|c|c|c|c|c|c|c|}
\hline \multirow{2}{*}{ Indices } & \multicolumn{4}{|l|}{ Diets $^{4}$} & \multirow{2}{*}{ SEM } & \multirow{2}{*}{$P$-value } \\
\hline & control & $\mathrm{CA}$ & $\mathrm{CA}-\mathrm{SeY}$ & $\mathrm{CA}-\mathrm{SeVI}$ & & \\
\hline \multicolumn{7}{|l|}{ Concentration } \\
\hline C10:0 & $0.117^{a}$ & $0.083^{b}$ & $0.089^{b}$ & $0.072^{b}$ & 0.002 & 0.04 \\
\hline $\mathrm{C} 12: 0$ & 0.121 & 0.101 & 0.150 & 0.117 & 0.011 & 0.16 \\
\hline $\mathrm{C} 14: 0$ & $3.46^{b}$ & $4.43^{\mathrm{a}}$ & $4.41^{\mathrm{a}}$ & $3.62^{b}$ & 0.09 & 0.04 \\
\hline C16:0 & 267.4 & 257.8 & 247.2 & 289.2 & 7.4 & 0.28 \\
\hline C17:0 & $15.2^{\mathrm{a}}$ & $11.5^{\mathrm{ab}}$ & $10.3^{b}$ & $11.2^{b}$ & 0.04 & 0.03 \\
\hline C18:0 & 395.9 & 347.5 & 336.8 & 373.9 & 4.3 & 0.16 \\
\hline $\mathrm{C} 22: 0$ & $3.39^{a}$ & $2.88^{b}$ & $0.11^{c}$ & $0.13^{c}$ & 0.07 & 0.03 \\
\hline A-SFA & 270.9 & 262.2 & 251.6 & 292.8 & 7.5 & 0.35 \\
\hline T-SFA & 664.5 & 607.7 & 588.4 & 666.7 & 12.7 & 0.29 \\
\hline$\Sigma$ SFA & $685.5^{\mathrm{a}}$ & $624.0^{\mathrm{bc}}$ & $601.6^{c}$ & $679.5^{\mathrm{ab}}$ & 2.9 & 0.04 \\
\hline$\sum F A$ & $2100^{\mathrm{ab}}$ & $1949^{b c}$ & $1756^{c}$ & $2171^{a}$ & 18 & 0.04 \\
\hline $\mathrm{A}-\mathrm{SFA} / \Sigma \mathrm{FA}$ & $0.129^{c}$ & $0.135^{a}$ & $0.145^{b}$ & $0.135^{a}$ & 0.001 & 0.03 \\
\hline T-SFA/LFA & 0.318 & 0.314 & 0.336 & 0.307 & 0.004 & 0.17 \\
\hline 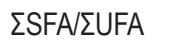 & $0.485^{b}$ & $0.471^{\mathrm{bc}}$ & $0.521^{\mathrm{a}}$ & $0.455^{c}$ & 0.003 & 0.03 \\
\hline 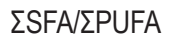 & $0.651^{b}$ & $0.636^{\mathrm{bc}}$ & $0.703^{a}$ & $0.603^{c}$ & 0.004 & 0.04 \\
\hline$\Sigma \mathrm{SFA} / \Sigma \mathrm{FA}$ & 0.329 & 0.322 & 0.344 & 0.312 & 0.005 & 0.16 \\
\hline
\end{tabular}

SEM - standard error of the mean; ${ }^{\mathrm{a}-\mathrm{c}}$ - means with different superscripts within a row differ significantly at $P \leq 0.05 ;{ }^{1} \mathrm{~A}-\mathrm{SFA}-$ the sum of $\mathrm{C} 12: 0$, C14:0 and C16:0; ${ }^{2}$ T-SFA - the sum: C14:0, C16:0 and C18:0; ${ }^{3}$ ISFA - the sum of C10:0, C11:0, C12:0, C13:0, C14:0, C15:0, C16:0, C17:0, $\mathrm{C} 18: 0, \mathrm{C} 20: 0$ and $\mathrm{C} 22: 0 ;{ }^{4}$ diets: control - basal diet containing $20 \mathrm{~g}$ of rapeseed oil (R-O) and $10 \mathrm{~g}$ of fish oil (F-O), CA - basal diet containing $20 \mathrm{~g}$ of R-O and $10 \mathrm{~g}$ of F-O with $1 \mathrm{~g}$ of carnosic acid (C-A), CA-SeY - basal diet containing $20 \mathrm{~g}$ of R-O and $10 \mathrm{~g}$ of F-O with $1 \mathrm{~g}$ of C-A and $0.35 \mathrm{mg}$ of Se as Se-enriched yeast, CA-SeVI - basal diet containing $20 \mathrm{~g}$ of R-O and $10 \mathrm{~g}$ of F-O with $1 \mathrm{~g}$ of C-A and $0.35 \mathrm{mg}$ of Se as selenate $(\mathrm{Se}-\mathrm{VI})$

Table 4. The concentrations (mg/100 g kidneys) of selected individual monounsaturated fatty acids (MUFAs), the concentration sum of all

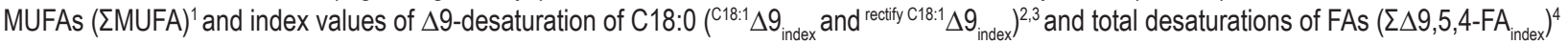
in the kidneys of lambs fed control and experimental diets

\begin{tabular}{|c|c|c|c|c|c|c|}
\hline \multirow{2}{*}{ Indices } & \multicolumn{4}{|l|}{ Diets $^{5}$} & \multirow{2}{*}{ SEM } & \multirow{2}{*}{$P$-value } \\
\hline & control & $\mathrm{CA}$ & $\mathrm{CA}-\mathrm{SeY}$ & CA-SeVI & & \\
\hline \multicolumn{7}{|l|}{ Concentration } \\
\hline c7C16:1 & $7.31^{\mathrm{a}}$ & $4.79^{b}$ & $2.52^{\mathrm{c}}$ & $0.08^{d}$ & 0.3 & 0.02 \\
\hline c9C16:1 & $6.82^{\mathrm{a}}$ & $4.26^{b}$ & $2.82^{\mathrm{c}}$ & $0.03^{d}$ & 0.2 & 0.03 \\
\hline c9C18:1 & 309.9 & 292.4 & 265.6 & 325.6 & 5.7 & 0.38 \\
\hline c12C18:1 & $36.8^{\mathrm{a}}$ & $31.7^{\mathrm{b}}$ & $26.8^{c}$ & $39.8^{\mathrm{a}}$ & 0.7 & 0.03 \\
\hline c11C20:1 & 0.0214 & 0.0206 & 0.0178 & 0.0231 & 0.0014 & 0.31 \\
\hline c13C22:1 & 0.0023 & 0.0018 & 0.0017 & 0.0023 & 0.0004 & 0.10 \\
\hline ¿MUFA & 360.8 & 343.0 & 297.7 & 365.4 & 8.7 & 0.28 \\
\hline${ }^{C 18: 1} \Delta 9_{\text {index }}$ & $0.44050^{c}$ & $0.45834^{b}$ & $0.44085^{c}$ & $0.46550^{a}$ & 0.00081 & 0.04 \\
\hline rectify $C 18: 1 \Delta 9_{\text {index }}$ & $0.44052^{c}$ & $0.45836^{b}$ & $0.44087^{c}$ & $0.46552^{\mathrm{a}}$ & 0.00082 & 0.04 \\
\hline$\Sigma \Delta 9,5,4-F A_{\text {index }}$ & $0.6808^{c}$ & $0.6859^{b}$ & $0.6629^{d}$ & $0.6913^{\mathrm{a}}$ & 0.001 & 0.03 \\
\hline$\Sigma M U F A / \Sigma F A$ & 0.171 & 0.179 & 0.170 & 0.169 & 0.003 & 0.39 \\
\hline
\end{tabular}

SEM - standard error of the mean; ${ }^{a-d}$ - means with different superscripts within a row differ significantly at $P \leq 0.05 ;{ }^{1} \sum M U F A$ - the sum of $c 7 C 16: 1$, c9C16:1, c9C17:1, t9C18:1, t11C18:1, c6C18:1, c7C18:1, c9C18:1, c11C18:1, c12C18:1, c11C20:1, c11C22:1 and $c 13 \mathrm{C} 22: 1: 2 \mathrm{C} 18: 1 \Delta 9_{\text {index }}=$ $c 9 C 18: 1 /(c 9 C 18: 1+C 18: 0) ;{ }^{3}$ rectify $C 18: 1 \Delta 9_{\text {index }}=(c 9 C 18: 1+c 11 C 20: 1+c 13 C 22: 1) /(c 9 C 18: 1+c 11 C 20: 1+c 13 C 22: 1+C 18: 0) ;{ }^{4}$ index of $\Delta 9-$, $\Delta 5$ - and $\Delta 4$-desaturations of FA $=($ LMUFA + EPUFA $) /\left(\mathrm{C} 14: 0+\mathrm{C} 16: 0+\mathrm{C} 18: 0+\sum M U F A+\sum P U F A\right) ;{ }^{5}$ diets: control - basal diet containing $20 \mathrm{~g}$ of rapeseed oil (R-O) and $10 \mathrm{~g}$ of fish oil (F-O), CA - basal diet containing $20 \mathrm{~g}$ of $\mathrm{R}-\mathrm{O}$ and $10 \mathrm{~g}$ of $\mathrm{F}-\mathrm{O}$ with $1 \mathrm{~g}$ of carnosic acid (C-A), CA-SeY basal diet containing $20 \mathrm{~g}$ of R-O and $10 \mathrm{~g}$ of F-O with $1 \mathrm{~g}$ of C-A and $0.35 \mathrm{mg}$ of Se as Se-enriched yeast, CA-SeVl - basal diet containing $20 \mathrm{~g}$ of R-O and $10 \mathrm{~g}$ of F-O with $1 \mathrm{~g}$ of C-A and $0.35 \mathrm{mg}$ of Se as selenate (Se-VI) 
with the control and CA-SeY diets. On the other hand, the experimental diet enriched in Se-Y reduced $(P \leq 0.05)$ the value of $\Sigma \Delta 9,5,4-\mathrm{FA}_{\text {index }}$ in kidneys when compared to the control, CA and CA-SeVI diets.

Table 5 shows the effect of the experimental diets on concentrations of individual PUFAs, concentration sums of PUFAs, ratios of PUFAs to FAs and values of desaturation indices. All experimental diets decreased $(P \leq 0.05)$ concentrations of $c 9 t$ 11CLA, c8c11c14C20:3, AA, c7c10c13c16C22:4, DPA, DHA, sums of n-3PUFAs ( $\Sigma$ n-3PUFA), n-6LPUFAs ( $\Sigma$ n-6LPUFA), LPUFAs ( $\Sigma$ LPUFA) and ratios of $\Sigma$ n-6LPUFA to $\Sigma F A, \Sigma$ LPUFA to $\Sigma F A, \Sigma$ PUFA to $\Sigma F A$ and $\Sigma$ PUFA to $\Sigma$ SFA in the kidneys compared to the control diet. Moreover, the CA diet also reduced $(P \leq 0.05)$ the concentrations of $\alpha$ LNA, $\Sigma$ n-6LPUFA and the $\Sigma$ n-6LPUFA/ $\Sigma$ n-3LPUFA ratio in the

Table 5. The concentrations (mg/100 $\mathrm{g}$ kidneys) of c9t11CLA, other ct/ctCLA isomers ( $\left.\sum c t / t c C L A\right)^{1}$, the sum of CLA isomers $\left(\sum C L A\right)^{2}$, selected

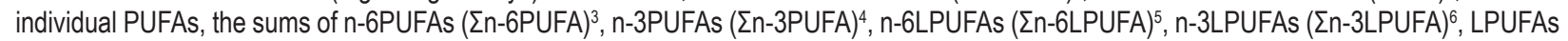
$(\Sigma L P U F A)^{7}$, all PUFAs $(\Sigma P U F A)^{8}$, ratios of selected FAs and indices of elongases and desaturases in the kidneys of lambs fed control and experimental diets

\begin{tabular}{|c|c|c|c|c|c|c|}
\hline \multirow{2}{*}{ Indices } & \multicolumn{4}{|l|}{ Diets $^{17}$} & \multirow{2}{*}{ - SEM } & \multirow{2}{*}{$P$-value } \\
\hline & control & $\mathrm{CA}$ & $\mathrm{CA}-\mathrm{SeY}$ & CA-SeVI & & \\
\hline \multicolumn{7}{|l|}{ Concentration } \\
\hline c9t11CLA & $1.397^{a}$ & $0.002^{b}$ & $0.002^{b}$ & $0.004^{b}$ & 0.004 & 0.03 \\
\hline c9c12C18:2 (LA) & 678.7 & 688.9 & 590.9 & 802.8 & 7.8 & 0.14 \\
\hline c9c12c15C18:3 (aLNA) & $5.5^{b}$ & $4.8^{c}$ & $5.3^{\mathrm{bc}}$ & $7.9^{a}$ & 0.2 & 0.03 \\
\hline c11c14C20:2 & $5.4^{b}$ & $5.3^{b}$ & $3.3^{\mathrm{a}}$ & $3.9^{a}$ & 0.3 & 0.04 \\
\hline c8c11c14C20:3 & $11.1^{a}$ & $8.4^{b}$ & $6.9^{c}$ & $8.0^{\mathrm{bc}}$ & 0.4 & 0.03 \\
\hline$c 5 c 8 c 11 c 14 C 20: 4(\mathrm{AA})$ & $280.9^{a}$ & $213.4^{\mathrm{bc}}$ & $195.6^{c}$ & $242.5^{b}$ & 3.9 & 0.02 \\
\hline c5c8c11c14c17C20:5 (EPA) & $18.2^{\mathrm{ab}}$ & $19.4^{a}$ & $15.4^{b}$ & $16.0^{b}$ & 0.2 & 0.04 \\
\hline c7c10c13c16C22:4 & $2.54^{a}$ & $1.98^{\mathrm{bc}}$ & $2.10^{b}$ & $1.63^{c}$ & 0.10 & 0.02 \\
\hline c7c10c13c16c19C22:5 (DPA) & $24.8^{\mathrm{a}}$ & $18.1^{\mathrm{bc}}$ & $16.7^{\mathrm{c}}$ & $20.5^{b}$ & 0.4 & 0.03 \\
\hline c4c7c10c13c16c19C22:5 (DHA) & $28.1^{\mathrm{a}}$ & $23.5^{b}$ & $22.5^{b}$ & $24.4^{b}$ & 0.2 & 0.04 \\
\hline$\sum n-6 P U F A$ & 970.7 & 910.7 & 793.4 & 1053.4 & 10.5 & 0.13 \\
\hline$\sum n-3 P U F A$ & $76.4^{\mathrm{a}}$ & $61.0^{\mathrm{b}}$ & $54.2^{\mathrm{b}}$ & $61.0^{b}$ & 1.6 & 0.03 \\
\hline$\sum n-6$ LPUFA & $299.9^{a}$ & $229.1^{b}$ & $208.8^{c}$ & $256.0^{b}$ & 4.1 & 0.03 \\
\hline 乏n-3LPUFA & $71.0^{\mathrm{a}}$ & $61.0^{\mathrm{ab}}$ & $54.2^{b}$ & $61.0^{\mathrm{ab}}$ & 1.7 & 0.03 \\
\hline$\Sigma$ LPUFA & $371.0^{\mathrm{a}}$ & $290.1^{\mathrm{bc}}$ & $263.1^{c}$ & $317.2^{b}$ & 7.1 & 0.02 \\
\hline 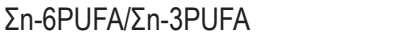 & $12.70^{c}$ & $14.93^{b}$ & $14.65^{b}$ & $17.27^{\mathrm{a}}$ & 0.13 & 0.04 \\
\hline 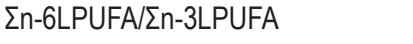 & $4.224^{a}$ & $3.756^{b}$ & $3.849^{b}$ & $4.198^{a}$ & 0.014 & 0.03 \\
\hline$\sum n-3 L P U F A / \Sigma F A^{9}$ & 33.8 & 31.3 & 30.9 & 28.1 & 0.7 & 0.14 \\
\hline$\sum n-6 L P U F A / \Sigma F A^{10}$ & $138^{a}$ & $113^{b}$ & $115^{b}$ & $114^{b}$ & 2 & 0.03 \\
\hline$\Sigma$ LPUFA/ $\Sigma F A^{11}$ & $177^{\mathrm{a}}$ & $130^{b}$ & $111^{c}$ & $128^{b}$ & 3 & 0.03 \\
\hline$\Sigma \mathrm{PUFA} / \Sigma F A$ & $0.503^{a}$ & $0.441^{b}$ & $0.364^{c}$ & $0.454^{b}$ & 0.005 & 0.03 \\
\hline$\Sigma \mathrm{PUFA} / \Sigma \mathrm{SFA}$ & $1.547^{a}$ & $1.411^{\mathrm{b}}$ & $1.186^{c}$ & $1.441^{b}$ & 0.009 & 0.02 \\
\hline n-3Elong22/20index ${ }^{12}$ & $0.588^{a}$ & $0.480^{c}$ & $0.525^{b}$ & $0.549^{b}$ & 0.005 & 0.03 \\
\hline n-6Elong20/18index ${ }^{13}$ & $0.00787^{a}$ & $0.00767^{b}$ & $0.00561^{c}$ & $0.00487^{d}$ & 0.00006 & 0.02 \\
\hline En-6Elong20/18index ${ }^{14}$ & $0.306^{a}$ & $0.250^{c}$ & $0.261^{b}$ & $0.242^{d}$ & 0.001 & 0.03 \\
\hline$\Delta 4_{\text {index }}{ }^{15}$ & $0.527^{b}$ & $0.556^{a}$ & $0.567^{a}$ & $0.526^{b}$ & 0.003 & 0.03 \\
\hline$\Delta 5_{\text {index }}{ }^{16}$ & $0.962^{b}$ & $0.962^{b}$ & $0.967^{a}$ & $0.968^{a}$ & 0.001 & 0.05 \\
\hline
\end{tabular}

CLA - conjugated linoleic acid; SEM - standard error of the mean; ${ }^{\text {a-d }}$ - means with different superscripts within a row differ significantly at $P \leq 0.05 ;{ }^{1} \sum \mathrm{ctt} / \mathrm{tcLA}$ - the sum of ct/tcCLA isomers: cis-transCLA: 11-13, 12-14; trans-cisCLA: 7-9, 8-10, 9-11, 10-12, 11-13 and 12-14; ${ }^{2} \Sigma C L A$ - the sum of $c 9 t 11 C L A, c t / t c C L A$ isomers, ttCLA isomers (trans-trans: 7-7, 8-10, 9-11, 10-12, 11-13 and 12-14) and ccCLA isomers (cis-cis: 8-10, 9-11, 10-12 and 11-12); ${ }^{3}$ En-6PUFA - the sum of LA, c11c14C20:2, c8c11c14C20:3, AA and c7c10c13c16C22:4; ${ }^{4} \sum \mathrm{n}-3 \mathrm{PUFA}-$ the sum of aLNA, $c 6 c 9 c 12 c 15 \mathrm{C} 18: 4$ and $\sum \mathrm{n}-3 \mathrm{LPUFA} ;{ }^{5} \sum \mathrm{n}-6 \mathrm{LPUFA}$ - the sum of $c 11 c 14 \mathrm{C} 20: 2, c 8 c 11 c 14 \mathrm{C} 20: 3$, AA and $c 7 c 10 c 13 c 16 \mathrm{C} 22: 4$; ${ }^{6} \Sigma n-3 L P U F A$ - the sum of EPA, DPA and DHA; ${ }^{7} \Sigma L P U F A-$ the sum of $\Sigma n-6 L P U F A$ and $\Sigma n-3 L P U F A ;{ }^{8} \Sigma P U F A-$ the sum of $\Sigma C L A, \Sigma n-3 P U F A$ and $\sum \mathrm{n}-6 \mathrm{PUFA} ;{ }^{9}$ the concentration ratio of $\sum \mathrm{n}-3 \mathrm{LPUFA}(\mu \mathrm{g} / \mathrm{g})$ to the sum of all fatty acids $(\Sigma F \mathrm{~A})(\mathrm{mg} / \mathrm{g}) ;{ }^{10}$ the concentration ratio of $\sum \mathrm{n}-6 \mathrm{LPUFA}(\mu \mathrm{g} / \mathrm{g})$ to $\sum F A(\mathrm{mg} / \mathrm{g}) ;{ }^{11}$ the concentration ratio of $\sum \operatorname{LPUFA}(\mu \mathrm{g} / \mathrm{g})$ to $\sum F A(\mathrm{mg} / \mathrm{g}) ;{ }^{12} \mathrm{n}-3 \mathrm{Elong} 222120$ index $=\mathrm{DPA} /(\mathrm{DPA}+\mathrm{EPA}) ;{ }^{13} \mathrm{n}-6 \mathrm{Elong} 20 / 18$ index $=c 11 \mathrm{c} 14 \mathrm{C} 20: 2 \mathrm{l}$ $(c 11 c 14 C 20: 2+\mathrm{LA}) ; 14$ En-6Elong20/18index $=($ c11c14C20:2 + c8c11c14C20:3 + AA + c7c10c13c16C22:4) / (LA + c11c14C20:2 + c8c11c14C20:3 +

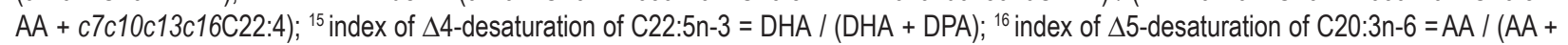
c8c11c14C20:3); ${ }^{17}$ diets: control - basal diet containing $20 \mathrm{~g}$ of rapeseed oil (R-O) and $10 \mathrm{~g}$ of fish oil (F-O), CA - basal diet containing $20 \mathrm{~g}$ of R-O and $10 \mathrm{~g}$ of F-O with $1 \mathrm{~g}$ of carnosic acid (C-A), CA-SeY - basal diet containing $20 \mathrm{~g}$ of R-O and $10 \mathrm{~g}$ of F-O with $1 \mathrm{~g}$ of C-A and $0.35 \mathrm{mg}$ of Se as Se-enriched yeast, CA-SeVI - basal diet containing $20 \mathrm{~g}$ of R-O and $10 \mathrm{~g}$ of F-O with $1 \mathrm{~g}$ of C-A and $0.35 \mathrm{mg}$ of Se as selenate (Se-VI) 
kidneys in comparison to the control diet. Compared to the control diet, all experimental diets increased the concentration ratio of $\Sigma$ n-6PUFA to $\Sigma$ n-3PUFA in the kidneys.

All experimental diets decreased $(P \leq 0.05)$ values of LA (n-6Elong20/18index) and EPA (n-3Elong22/20index) elongation indices when compared to the control diet. The experimental diet containing C-A alone or with Se-Y increased $(P \leq 0.05)$ values of the $\Delta 4$-desaturase index $\left(\Delta 4_{\text {index }}\right)$ compared to the control and CA-SeVI diets. The experimental diets enriched in Se-Y or Se-VI increased $(P \leq 0.05)$ values of the $\Delta 5$-desaturase index $\left(\Delta 5_{\text {index }}\right)$ in the kidneys when compared to the control and CA diets.

\section{Impact of the experimental diets on concentrations of $\mathrm{T}-\mathrm{Ch}$ and tocopherols, oxidative stress and thrombogenic and atherogenic indexes in the lamb kidneys}

In the current experiment, the CA diet resulted in the decrease $(P \leq 0.05)$ in the concentrations of $\gamma$-tocopherol $(\gamma-\mathrm{T}), \alpha$-tocopheryl acetate $(\alpha-\mathrm{TAc})$ and the sum of all assayed tocopherols (Eall-Ts) in the kidneys when compared with the control diet (Table 6). Similarly, the lower concentrations of $\Sigma$ all-Ts and the sum of $\alpha$-T and $\alpha$-TAc $(\Sigma(\alpha-T+\alpha-$ TAc)) were found in the kidneys of lambs fed the CA-SeVI diet than in the one fed the control diet. Moreover, Se-VI added to the experimental diet reduced $(P \leq 0.05)$ the concentrations of $\alpha$-TAc,
$\Sigma(\alpha-\mathrm{T}+\alpha-\mathrm{TAc})$ and $\Sigma$ all-Ts in comparison to the kidneys of the lambs fed the diet enriched with Se-Y. As shown in Table 6, the addition of Se-Y or Se-VI to the experimental diet decreased the concentration of MDA in the kidneys compared to the control and CA diets. Interestingly, values of the PUFAs peroxidation indices ( ${ }^{\mathrm{PUFA}} \mathrm{MDA}_{\text {index }}$ and ${ }^{\mathrm{PUFA}-}$ ${ }_{\text {LHPUFA }} \mathrm{MDA}_{\text {index }}$ ) were the lowest in the kidneys of lambs fed the experimental diet enriched with SeVI than the control, CA and CA-SeY diets. The CA diet resulted in an increase $(P \leq 0.05)$ in the values of the PUFAs peroxidation indices compared to the control, CA-SeY and CA-SeVI diets.

The effects of the experimental diets on the $\mathrm{h} / \mathrm{H}-\mathrm{Ch}$ ratio and values of ${ }_{\text {index }} \mathrm{T}^{\mathrm{SFA}}$, index $\mathrm{A}^{\mathrm{SFA}}$ and index $\mathrm{A}^{\mathrm{SFA}+\mathrm{Toc}}$ in the kidneys are provided in Table 7. Lower $\mathrm{h} / \mathrm{H}-\mathrm{Ch}$ ratio values and higher values of index ${ }^{\mathrm{T} F A}$ were observed in the kidneys of lambs fed experimental diets than the control diet $(P \leq 0.05)$. The $\mathrm{CA}-\mathrm{SeY}$ diets decreased the $\mathrm{h} / \mathrm{H}-\mathrm{Ch}$ ratio value in the kidneys compared to the control, CA and $\mathrm{CA}-\mathrm{SeVI}$ diets. Moreover, the CA-SeY diet increased $(P \leq 0.05)$ values of ${ }_{\text {index }} \mathrm{T}^{\mathrm{SFA}}$ and ${ }_{\text {index }} \mathrm{A}^{\mathrm{SFA}}$ when compared to control, CA and CA-SeVI diets. The highest value of ${ }_{\text {index }} \mathrm{A}^{\mathrm{SFA} A \text { Toc }}$ was observed in the kidneys of lambs fed the CA-SeVI diet than control, $\mathrm{CA}$ and CA-SeY diets $(P \leq 0.05)$. The value of index $A^{\text {SFA+Toc }}$ was higher $(P \leq 0.05)$ in the kidneys of lambs fed CA and CA-SeY diets than the control diet.

Table 6. The concentrations of total cholesterol (T-Ch; $\mathrm{mg} / 100 \mathrm{~g}$ tissue), tocopherols ( $\mathrm{mg} / 100 \mathrm{~g}$ tissue) and MDA ( $\mathrm{ng} / \mathrm{g}$ tissue) ${ }^{1}$ and values of the PUFAs peroxidation indices (PUFAMDA ${ }_{\text {index }}$ and PUFA-LHPUFA MDA ${ }_{\text {index }}$ ) in the kidneys of lambs fed control and experimental diets

\begin{tabular}{|c|c|c|c|c|c|c|}
\hline \multirow{2}{*}{ Indices } & \multicolumn{4}{|l|}{ Diets $^{5}$} & \multirow{2}{*}{ SEM } & \multirow{2}{*}{$P$-value } \\
\hline & control & $\mathrm{CA}$ & $\mathrm{CA}-\mathrm{SeY}$ & $\mathrm{CA}-\mathrm{SeVI}$ & & \\
\hline $\mathrm{T}-\mathrm{Ch}$ & 78.9 & 87.2 & 100.7 & 95.8 & 4.1 & 0.09 \\
\hline$\delta$-tocopherol $(\delta-T)$ & 0.216 & 0.215 & 0.153 & 0.215 & 0.017 & 0.27 \\
\hline y-tocopherol $(\mathrm{V}-\mathrm{T})$ & $0.175^{\mathrm{a}}$ & $0.120^{b}$ & $0.113^{b}$ & $0.170^{a}$ & 0.005 & 0.04 \\
\hline a-tocopherol (a-T) & 0.448 & 0.411 & 0.411 & 0.287 & 0.017 & 0.13 \\
\hline a-tocopheryl acetate (a-TAc) & $0.149^{b}$ & $0.124^{c}$ & $0.224^{a}$ & $0.135^{b c}$ & 0.003 & 0.02 \\
\hline$\Sigma(\alpha-T+\alpha-T A c)$ & $0.598^{\mathrm{ab}}$ & $0.535^{b}$ & $0.636^{a}$ & $0.422^{c}$ & 0.007 & 0.03 \\
\hline ¿all-Ts ${ }^{2}$ & $0.988^{a}$ & $0.870^{b c}$ & $0.901^{a b}$ & $0.807^{c}$ & 0.007 & 0.04 \\
\hline MDA & $0.701^{b}$ & $0.750^{a}$ & $0.610^{c}$ & $0.615^{c}$ & 0.008 & 0.03 \\
\hline 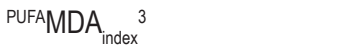 & $0.666^{c}$ & $0.762^{a}$ & $0.710^{b}$ & $0.545^{d}$ & 0.012 & 0.02 \\
\hline PUFA-LHPUFAMDA ${ }_{\text {index }}{ }^{4}$ & $0.327^{c}$ & $0.408^{a}$ & $0.372^{\mathrm{b}}$ & $0.297^{d}$ & 0.004 & 0.02 \\
\hline
\end{tabular}

MDA - malondialdehyde; PUFA - polyunsaturated fatty acids; SEM - standard error of the mean; ${ }^{\text {a-c }}$ - means with different superscripts within a row differ significantly at $P \leq 0.05 ;{ }^{1}$ concentrations of MDA were determined immediately after the homogenization of the kidney samples; ${ }^{2}$ the concentration sum of all tocopherols: $\sum$ all-Ts $=\delta-T+\gamma-T+a-T+a-T A c ;{ }^{3}$ the concentration ratio of MDA (ng/g tissue) to $\Sigma P U F A$ (mg/g tissue); ${ }^{4}$ the concentration ratio of MDA (ng/g tissue) to the sum of $\Sigma$ PUFA and highly unsaturated PUFAs possessing 4 or more double bonds ( $\Sigma$ LHPUFA)

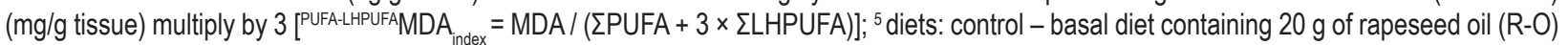
and $10 \mathrm{~g}$ of fish oil (F-O), CA - basal diet containing $20 \mathrm{~g}$ of R-O and $10 \mathrm{~g}$ of F-O with $1 \mathrm{~g}$ of carnosic acid (C-A), CA-SeY - basal diet containing $20 \mathrm{~g}$ of R-O and $10 \mathrm{~g}$ of F-O with $1 \mathrm{~g}$ of C-A and $0.35 \mathrm{mg}$ of Se as Se-enriched yeast, CA-SeVI - basal diet containing $20 \mathrm{~g}$ of R-O and $10 \mathrm{~g}$ of $\mathrm{F}-\mathrm{O}$ with $1 \mathrm{~g}$ of $\mathrm{C}-\mathrm{A}$ and $0.35 \mathrm{mg}$ of $\mathrm{Se}$ as selenate $(\mathrm{Se}-\mathrm{VI})$ 
Table 7. The hypocholesterolemic/hypercholesterolemic fatty acids $(\mathrm{h} / \mathrm{H}-\mathrm{Ch})$ ratio ${ }^{1}$ and the thrombogenic $\left({ }_{\text {index }} \mathrm{T}^{\mathrm{SFA}}\right)^{2}$, atherogenic $\left.{ }_{\text {index }} \mathrm{A}^{\mathrm{SFA}}\right)^{3}$ and modified atherogenic $\left.{ }_{\text {index }} \mathrm{A}^{\mathrm{SFA}+\mathrm{Toc}}\right)^{4}$ indices in the kidneys of lambs fed control and experimental diets

\begin{tabular}{|c|c|c|c|c|c|c|}
\hline \multirow{2}{*}{ Indices } & \multicolumn{4}{|l|}{ Diets $^{5}$} & \multirow{2}{*}{ SEM } & \multirow{2}{*}{$P$-value } \\
\hline & control & $\mathrm{CA}$ & $\mathrm{CA}-\mathrm{SeY}$ & CA-SeVI & & \\
\hline $\mathrm{h} / \mathrm{H}-\mathrm{Ch}$ ratio & $5.232^{\mathrm{a}}$ & $5.061^{b}$ & $4.599^{\circ}$ & $5.099^{b}$ & 0.012 & 0.02 \\
\hline index ${ }^{\text {SFA }}$ & $0.495^{c}$ & $0.516^{b}$ & $0.550^{\mathrm{a}}$ & $0.509^{b}$ & 0.004 & 0.03 \\
\hline index $A^{\text {SFA }}$ & $0.200^{c}$ & $0.209^{b}$ & $0.234^{\mathrm{a}}$ & $0.204^{b c}$ & 0.001 & 0.04 \\
\hline index $A^{\text {SFA+Toc }}$ & $0.0221^{\mathrm{c}}$ & $0.0258^{b}$ & $0.0248^{b}$ & $0.0316^{a}$ & 0.0002 & 0.02 \\
\hline
\end{tabular}

SEM - standard error of the mean; ${ }^{\mathrm{a}-c}-$ means with different superscripts within a row differ significantly at $P \leq 0.05 ;{ }^{1} \mathrm{~h} / \mathrm{H}-\mathrm{Ch}$ ratio $=(c 7 \mathrm{C} 16: 1+$ $c 9 \mathrm{C} 16: 1+c 9 \mathrm{C} 18: 1+c 12 \mathrm{C} 18: 1+c 11 \mathrm{C} 20: 1+c 13 \mathrm{C} 22: 1+\mathrm{LA}+\mathrm{aLNA}+\mathrm{AA}+c 11 c 14 \mathrm{C} 20: 2+\mathrm{EPA}+\mathrm{c7c10c13c16C22:4+DPA}+\mathrm{DHA}) /(\mathrm{C} 14: 0+$ C16:0) (Fernández et al., 2007); ${ }^{2}$ index ${ }^{\text {SFA }}=\left(\right.$ C14:0 + C16:0 + C18:0) $/\left(0.5 \times \sum M U F A+0.5 \times \sum n-6 P U F A+3 \times \sum n-3 P U F A+\sum n-3 P U F A / \Sigma n-6 P U F A\right)$ (Morán et al., 2013); ${ }^{3}$ index $A^{\text {SFA }}=(C 12: 0+4 \times C 14: 0+C 16: 0) /\left(\sum M U F A+\sum n-6 P U F A+\sum n-3 P U F A\right)\left(\right.$ Morán et al., 2013); ${ }^{4}$ index $A^{\text {SFA+Toc }}={ }_{\text {index }} A^{\text {SFA }}$ $\left(1.49 \times \mathrm{C}_{\mathrm{aT}}+1.36 \times \mathrm{C}_{\mathrm{aTAC}}+0.15 \times \mathrm{C}_{\mathrm{\gamma T}}+0.05 \times \mathrm{C}_{\delta \mathrm{T}}\right)$, where $\mathrm{C}_{\mathrm{aT}}, \mathrm{C}_{\mathrm{aTAC}}, \mathrm{C}_{\mathrm{\gamma T}}, \mathrm{C}_{\delta \mathrm{T}}-$ the concentration $(\mu \mathrm{g} / \mathrm{g})$ of a-tocopherol, a-tocopheryl acetate, $\mathrm{Y}$-tocopherol and $\delta$-tocopherol, respectively; ${ }^{5}$ diets: control - basal diet containing $20 \mathrm{~g}$ of rapeseed oil (R-O) and $10 \mathrm{~g}$ of fish oil (F-O), CA-basal diet containing $20 \mathrm{~g}$ of R-O and $10 \mathrm{~g}$ of F-O with $1 \mathrm{~g}$ of carnosic acid (C-A), CA-SeY - basal diet containing $20 \mathrm{~g}$ of R-O and $10 \mathrm{~g}$ of F-O with $1 \mathrm{~g}$ of C-A and $0.35 \mathrm{mg}$ of Se as Se-enriched yeast, CA-SeVI - basal diet containing $20 \mathrm{~g}$ of R-O and $10 \mathrm{~g}$ of F-O with $1 \mathrm{~g}$ of C-A and $0.35 \mathrm{mg}$ of $\mathrm{Se}$ as selenate (Se-VI)

\section{Discussion}

\section{Effect of the diets enriched in C-A, Se-Y and Se-VI on the internal organs and concentrations of fatty acids in the kidneys}

The results of our current and previous studies showed that no visual toxic symptoms and macroscopic lesions of dietary Se (like renal failure, respiratory distress syndrome, neurological features including tremors and vascular symptoms such as tachycardia) were observed in animals fed experimental diets enriched with F-O, R-O, C-A and Se (as Se-Y or Se-VI) (Rozbicka-Wieczorek et al., 2016a,b; Czauderna et al., 2017, 2018; Białek et al., 2018). In fact, chronic dietary exposure to Se-compounds, especially selenides or selenite, at rates of more than $5 \mathrm{mg}$ Se per $\mathrm{kg}$ diet can be teratogenic and hepatotoxic in ruminants and humans (Navarro-Alarcon and Cabrera-Vique, 2008). The results of our previous studies documented that the experimental diets containing C-A, irrespective of the presence of Se-Y or Se-VI, ensured optimal ruminal fermentation conditions, which was confirmed by the acetic acid/propionic acid ratio in ruminal fluids greater than 2.2:1 (Wolin, 1979). Moreover, the CA-SeVI diet decreased ruminal methanogenesis, as this experimental diet reduced $(P \leq 0.05)$ ruminal amounts of $\mathrm{CH}_{4}$ (the highenergy compound) and $\mathrm{CO}_{2}$ when compared to the control and CA-SeY diets (Białek and Czauderna, 2019). On the other hand, the CA-SeY diet stimulated methanogenesis compared to the control, $\mathrm{CA}$ and CA-SeVI diets (Białek and Czauderna, 2019). Unfortunately, $\mathrm{CH}_{4}$ and $\mathrm{CO}_{2}$ (the greenhouse gases - waste products) cause the loss of $\sim 8 \%$ of the total digestible energy of the diet (Wolin, 1979). That is why in the present study the experimental diet supplemented with Se-VI increased the BW of lambs, FCE and so kidney weight, especially in comparison to the CA and CA-SeY diets (Table 2). Compared to the experimental diet enriched with Se-VI (the inorganic form of Se), the $\mathrm{CA}$ and CA-SeY diets alleviated the increase in kidney weight. This relationship is consistent with the influence of the experimental diets with C-A and especially Se-VI and Se-Y on the concentration of $\Sigma F A$ in the kidneys. Indeed, knowing that Se content in whole blood, liver, heart or muscle increased in lambs fed the experimental diets enriched with $\mathrm{Se}$ (as Se-VI or Se-Y) and C-A (Table 2; Czauderana et al., 2017; 2018), we can assume that also in the kidney such increase was stated. As a consequence, the concentration of $\Sigma F A$ was lower in the kidneys of lambs fed CA $(10 \%)$ and CA-SeY (19\%) diets than the CA-SeVI diet. Considering the above, we argued that especially the CA-SeY diet may protect against the development of lipid-induced renal damage (i.e. the lipid nephrotoxicity) (Gai et al., 2019). Indeed, hyperlipidemia in kidneys can lead to the production of reactive oxygen species, inflammation and endogenous electrical stress. Renal lipid accumulation can cause structural and functional changes in mesangial cells, podocytes and proximal tubule cells. The renal proximal tubule cells are the main place of lipid accumulation in the kidney. High contents of albumin-bound long-chain SFAs were shown to stimulate renal tubular damage and interstitial fibrosis; excess of oxidized-HDL-C in kidneys induced pro-inflammatory pathways and interleukin-6 (Gai et al., 2019). As the obtained data showed, the experimental diet enriched in Se-Y (rich in Se-Met) 
most efficiently reduced the concentrations of SFAs, MUFAs and PUFAs in the kidneys as compared to control, CA and particularly CA-SeVI diets. Thus, our present results are in agreement with studies of Navarro-Alarcon and Cabrera-Vique (2008), in which the concept that antioxidative properties of seleno-biomolecules depend upon chemical forms of Se added to mammals' diets. In fact, the different bioavailability of Se from dietary Se-Y (rich in Se-Met) and Se from dietary Se-VI resulted from the higher bioaccumulation of Se as Se-Met in the kidneys' proteins of lambs fed the CA-SeY diet than the CA-SeVI diet. Unfortunately, Se-Met-containing proteins are less effective in the detoxification of reactive oxygen and nitrogen species than Se-Cys containing enzymes derived mainly from dietary Se-VI or selenite (Suzuki, 2005; NavarroAlarcon and Cabrera-Vique, 2008). Thus, our present results are in agreement with studies in which weaker antioxidant properties of antioxidants (e.g., Se-Met-containing proteins) resulted in more efficient catalysis of hydrosulphide oxidation; this effect causes the reduction of the biosynthesis yield of lipogenic enzymes (e.g., acetyl-CoA carboxylase and fatty acid synthase) responsible for the biosynthesis of fatty acids (Rayman, 2004; Suzuki, 2005; Navarro-Alarcon and Cabrera-Vique, 2008). In this context, it should be emphasized that kidneys are the organs that accumulate the highest concentration of Se followed by the liver, testis and lungs (Czauderna and Smogorzewska, 1986). Moreover, especially kidneys (like liver) play an important role in Se metabolism as an excess of dietary Se is excreted mainly in the urine.

Our results documented that compared to control, $\mathrm{CA}$ and $\mathrm{CA}-\mathrm{SeY}$ diets, the experimental diet containing Se-VI (the less bioavailable form of $\mathrm{Se}$ ) increased the capacity of $\Delta 9$-desaturase (i.e. ${ }^{\mathrm{C} 18: 1} \Delta 9_{\text {index }}$ and rectifyc18:1 $\Delta 9_{\text {index }}$ ) in the kidneys. Thus, the results of the current study are in agreement with our previous investigation (Krajewska et al., 2012) in which Se-VI added to the diet enriched with linseed oil, increased the index value of $\Delta 9$ desaturation of C18:0 in the lamb kidneys compared to the diet with only linseed oil. Similarly, compared to the control and CA-SeY diets, the experimental diet enriched in Se-VI and CA increased the $\Delta 9$-desaturation capacity. Moreover, the experimental diet enriched only in C-A increased the $\Delta 9$-desaturation capacity, although not as effective as the CA-SeVI diet. In fact, Se-biomolecules, as well as tocopherols (the antioxidants), are involved in the desaturation of n-3PUFA and n-6PUFA by participating in the microsomal electron transport chain (Infante, 1986). So, our current study documented that dietary Se-VI stimulated biosynthesis of Se-biomolecule(s) involved in the desaturation of n-3PUFA and n-6PUFA. Furthermore, we argued that dietary C-A (the antioxidant), like tocopherols, elevated the desaturation of PUFA by participating in the microsomal electron transport chain.

The opposite phenomenon was observed in the presence of Se-Y in the experimental diet because the organic forms of Se have not changed the values of ${ }^{C 18: 1} \Delta 9_{\text {index }}$ and rectifyc18:1 $\Delta 9_{\text {index }}$ in the kidneys compared to the control diet. Thus, our results confirm the results of the earlier study of Haug et al. (2007) who found that a diet enriched in Se-Y (rich in highly-bioavailable Se-Met) has no influence on $\Delta 9$-desaturation of $\mathrm{C} 18: 0$ in muscles in experimental animals. Considering the above, we argued that the capacity of $\Delta 9$-desaturase is not increased by the higher concentration of Se in tissues. Furthermore, we suggest that Se-Met incorporated into protein in place of Met (Navarro-Alarcon and Cabrera-Vique, 2008) revealed the negligible impact on the $\Delta 9$-desaturase capacity in the kidneys. On the other hand, our current study and other investigation documented that the experimental diet containing organic forms of Se stimulated the capacity of $\Delta 4$ - and $\Delta 5$-desaturases in the kidneys, liver (Czauderna et al., 2011a) and muscles (Haug et al., 2007) as compared to the control diet. Similarly, the diet enriched in the inorganic form of Se elevated the $\Delta 5$-desaturase capacity compared to control and CA diets. Thus, our study is in agreement with the previous studies in which the capacity of $\Delta 4-, \Delta 5$ - and $\Delta 6$-desaturase was positively correlated with the level of Se-dependent enzymes and hormones as well as Se contents in diets (Ahmad et al., 2012).

Our studies revealed that C-A added to the diet, irrespective of the presence of Se, reduced the concentration of c9t11CLA and the capacity of UFAs elongation to LPUFAs in the kidneys as compared to the control diet. Similarly, our recent investigation showed that the experimental diet containing C-A, regardless of the presence of Se-Y and Se-VI, reduced the concentrations of $c 9 t 11 \mathrm{CLA}$ and LPUFAs in ovine ruminal fluid (Białek et al., 2018; Białek and Czauderna, 2019). In fact, dietary C-A (in a dose-dependent manner) affects the profile, growth and activity of ruminal microorganisms, the capacity of bacterial isomerisation and biohydrogenation of UFAs and, hence, the ruminal biosynthesis of FAs and the FAs profiles in lambs tissues 
(Morán et al., 2012a; 2013; 2017). Considering the above, we argued that dietary C-A stimulated catabolism of $c 9 t 11$ CLA and LPUFAs in ruminal fluids and kidneys of lambs. Moreover, the obtained $\Sigma$ n-6LPUFA and the $\Sigma$ n-6LPUFA/ $\Sigma$ FA ratios showed that the experimental diets enriched in C-A stimulated catabolism of n-6LPUFAs (AA in particular) in the kidneys. Thus, our current and previous studies (Białek et al., 2018; Białek and Czauderna, 2019) are in agreement with the results of Lee et al. (2018) in which dietary C-A suppressed fatty acid synthesis and stimulated $\beta$-oxidation of fatty acids (especially c9t11CLA and n-6LPUFAs).

\section{Tocopherols, oxidative stress, hypocholes- terolemic/hypercholesterolemic FAs ratio and thrombogenic and atherogenic indices of the lamb kidneys}

The current study showed that compared to the control diet, the experimental diet enriched only in C-A reduced the concentrations of $\gamma$-T, $\alpha$-TAc and $\Sigma$ all-Ts in the kidneys. At the same time, the CA diet increased oxidative stress in the kidneys, as well as in the brain (Rozbicka-Wieczorek et al., 2016a), liver (Rozbicka-Wieczorek et al., 2016b), muscles (Czauderna et al., 2018), whole blood (Czauderna et al., 2017) and rumen-surrounding fat (Białek and Czauderna, 2019). Considering the above, it is clear that the CA diet, without additional antioxidants (Se-Y or Se-VI) revealed the strongest oxidative activity in the kidneys as compared to the control diet. This effect of dietary C-A on the peroxidase system in living organisms can be assigned to the fact that $\mathrm{C}$-A (the scavenger of reactive free radicals) could also act as a substrate for the peroxidase system. Therefore, C-A and carnosol (the product of oxidative biodegradation of C-A) can stimulate DNA damage as well as the oxidative degradation of PUFAs (Aruoma et al., 1992; Rozbicka-Wieczorek et al., 2016a,b; Czauderna et al., 2017). Furthermore, the current study is in agreement with our previous research in which a diet supplemented with F-O, sunflower oil and lycopene (the antioxidant) stimulated the bioformation of MDA in breast and thigh muscles of chickens (Rozbicka-Wieczorek et al., 2012).

Nowadays, the physiological property of $\alpha-\mathrm{T}$ that is of the greatest attention is the effective prevention of lipid peroxidation as well as the specific selection of RRR- $\alpha$-T by the hepatic $\alpha$-tocopherol transfer protein (Brigelius-Flohé and Traber, 1999). Importantly, $\alpha-\mathrm{T}$ is the most reactive tocopherol against peroxyl radicals, whereas $\delta$-T is the least reactive (i.e. $\alpha-\mathrm{T}>\beta-\mathrm{T}=\gamma-\mathrm{T}>\delta$-T (Zu and Ip, 2003)). Our present study supports the concept that dietary inorganic form of Se (Se-VI) reduced the regeneration process of $\alpha$-tocopheryl radicals (products of the antioxidant action of tocopherols derived from $\alpha-T$ and $\alpha$-TAc) in the kidneys when compared to the control and CA-SeY diets. On the other hand, dietary SeY most effectively stimulated the regeneration of $\alpha$-tocopheryl radicals derived from $\alpha$-TAc when compared to the control diet and diets containing C-A, irrespective of the presence of the inorganic form of Se. Furthermore, we suggested that the experimental diets enriched in antioxidants reduced the oxidative degradation of tocopherols and stimulated the regeneration of degraded tocopherols in ovine tissues (Morán et al., 2012a,b; 2017; Haliga et al., 2015; Čobanová et al., 2017).

Our previous studies suggested that the CA-SeY diet stimulated atherogenic properties in the kidneys and subcutaneous fat (KrajewskaBienias et al., 2017). Indeed, this experimental diet with $\mathrm{SeY}$ increased the A-SFA/ $\Sigma$ FA ratio as well as the values of ${ }_{\text {index }} \mathrm{A}^{\mathrm{SFA}}$ and ${ }_{\text {index }} \mathrm{A}^{\mathrm{SFA}+\mathrm{Toc}}$ in the kidneys. Atherogenesis, a multifactorial process, is stimulated by A-SFA (especially C14:0 (Yusháu, 2018)), whereas reduced by dietary n-3PUFAs (Haliga et al., 2015) and tocopherols (Saini et al., 2012). Recent studies showed that diets enriched in tocopherols and plant oils rich in n-3PUFAs had an anti-atherogenic effect (i.e. reduced aortic cholesterol concentration, intimal lipid infiltration and discrete alterations to the middle layer of the arterial wall) (Saini et al., 2012; Haliga et al., 2015). In fact, 'the oxidation theory' of antioxidant systems and atherosclerosis documented that oxidation of low-density lipoprotein cholesterol (LDL-C) significantly contributes to atherogenesis while dietary antioxidants (i.e. tocopherols or tocotrienols), co-antioxidants (ascorbate and ubiquinol-10) are able to prevent oxidation of LDL-C, cholesterol and UFAs in lipids, thus, delaying atherogenesis process in animals and humans (Salvayre et al., 2016). Considering the above, we argued that the atherogenic index should be calculated based on the concentrations of pro-atherogenic SFAs (i.e. A-SFA), MUFAs, n-6PUFAs, n-3PUFAs as well as the concentrations of anti-atherogenic tocopherols in tissues. In our opinion, compared with the index $\mathrm{A}^{\mathrm{SFA}}{ }_{\text {index }} \mathrm{A}^{\mathrm{SFA}+\mathrm{Toc}}$ provides more detailed insight into atherogenesis mechanisms and thus, possesses better predictive properties. 
In accordance with the above observations, values of the $\mathrm{h} / \mathrm{H}-\mathrm{Ch}$ ratio also indicated that all experimental diets, especially containing the organic Se-forms derived from Se-Y, stimulated cholesterolemic activity in the kidneys. In fact, the concentrations of FAs considered as hypocholesterolemic (like MUFAs, n-6PUFAs and especially n-3PUFAs) were lower in the kidneys of lambs fed the experimental diets, particularly with Se-Y, than the control diet. At the same time, the concentrations of hypercholesterolemic FAs (especially C14:0) were higher in the kidneys of lambs fed $\mathrm{CA}$ and CA-SeY diets than the control diet. Thus, similarly to our previous investigations, our current study indicates that the dosed amount of C-A in the experimental diets (the CA diet) stimulated hypercholesterolemia-induced oxidative stress, decreasing the activities of antioxidant enzymes and increasing the concentrations of reactive substances (Aruoma et al., 1992; Rozbicka-Wieczorek et al., 2016a,b; Czauderna et al., 2017). Importantly, oxidative stress is characterized by not only increased reactive chemical species formation but also decreased antioxidant enzyme activities (Afonso et al., 2013). Consequently, the concentration of MDA (the marker of the oxidative degradation of lipids) and the PUFAs peroxidation indices were higher in the kidneys, liver, brain and whole blood of lambs fed the CA diet than the control diet (Rozbicka-Wieczorek et al., 2016a,b; Czauderna et al., 2017).

\section{Conclusions}

The present research confirmed that dietary Se-enriched yeast (Se-Y) and selenate (Se-VI), as well as carnosic acid (C-A), have the ability to modify the metabolism of fatty acids, cholesterol and tocopherols in the kidneys. Se-Y or Se-VI added to the diet supplemented with $\mathrm{C}-\mathrm{A}$ reduced oxidative stress in the kidneys, whereas C-A supplemented to the diet without $\mathrm{Se}-\mathrm{Y}$ or Se-VI stimulated the oxidative degradation of polyunsaturated fatty acids (PUFAs). Our current study provides useful practical knowledge for nutritionists carrying out further studies aimed at improving the health and welfare of lambs as well as other farm ruminants. However, further investigations are necessary to determine if diets containing $\mathrm{C}-\mathrm{A}, \mathrm{Se}-\mathrm{Y}$ or $\mathrm{Se}-\mathrm{VI}$ along with fish and rapeseed oils induce changes in the contents of fatty acids, cholesterol and tocopherols, and intensity of lipid oxidation in other lamb organs (especially spleen and pancreas).

\section{Acknowledgements}

This study was supported by the National Science Centre (Poland) Grant no. 2013/09/B/ NZ9/00291 and by the statutory funds of The Kielanowski Institute of Animal Physiology and Nutrition, Polish Academy of Sciences (Jabłonna, Poland).

\section{Conflict of interest}

The authors declare that there is no conflict of interest.

\section{References}

Afonso M.S., de O Silva A.M., Carvalho E.B.T., Rivelli D.P., Barros S.B.M., Rogero M.M., Lottenberg A.M., Torres R.P., Mancini-Filho J., 2013. Phenolic compounds from Rosemary (Rosmarinus officinalis L.) attenuate oxidative stress and reduce blood cholesterol concentrations in diet-induced hypercholesterolemic rats. Nut. Metab. 10, 19, https://doi. org/10.1186/1743-7075-10-19

Ahmad H., Tian J., Wang J., Khan M.A., Wang Y., Zhang L., Wang T., 2012. Effects of dietary sodium selenite and selenium yeast on antioxidant enzyme activities and oxidative stability of chicken breast meat. J. Agric. Food Chem. 60, 7111-7120, https://doi.org/10.1021/jf3017207

AlBasher G., Alfarraj S., Alarifi S., Alkhtani S., Almeer R., Alsultan N., Alharthi M., Alotibi N., Al-dbass A., Moneim A.E.A., 2020. Nephroprotective role of selenium nanoparticles against glycerol-induced acute kidney injury in rats. Biol. Trace Elem. Res. 194, 444-454, https://doi.org/10.1007/s12011-01901793-5

AOAC International, 2005. Official Methods of Analysis of AOAC International. 18 $8^{\text {th }}$ Edition. Gaithersburg, MD (USA)

Aruoma O.I., Halliwell B., Aeschbach R., Löligers J., 1992. Antioxidant and pro-oxidant properties of active rosemary constituents: carnosol and carnosic acid. Xenobiotica 22, 257-268, https:// doi.org/10.3109/00498259209046624

Attia Y.A., Abd El-Hamid A.E., de Oliveira M.C., Kamel K.I., Qota E.M., Al-Harthi M.A., Sadaka T.A., 2018. Soya lecithin and season affect the productive performance, nutrient digestibility and blood constituents of growing rabbits. J. Anim. Feed Sci. 27, 36-43, https://doi.org/10.22358/jafs/80344/2018

Białek M., Czauderna M., 2019. Composition of rumen-surrounding fat and fatty acid profile in selected tissues of lambs fed diets supplemented with fish and rapeseed oils, carnosic acid, and different chemical forms of selenium. Livest. Sci. 226, 122-132, https://doi.org/10.1016/j.livsci.2019.06.013

Białek M., Czauderna M., Białek A., 2018. Partial replacement of rapeseed oil with fish oil, and dietary antioxidants supplementation affects concentrations of biohydrogenation products and conjugated fatty acids in rumen and selected lamb tissues. Anim. Feed Sci. Technol. 241, 64-74, https:// doi.org/10.1016/j.anifeedsci.2018.04.015

Białek M., Czauderna M., Zaworski K., 2020. Diets enriched in fish and rapeseed oils, carnosic acid, and different chemical forms of selenium affect fatty acid profile in the periintestinal fat and indices of nutritional properties of selected tissues of lambs. Agric. Food Sci. 29, 405-419, https://doi.org/10.23986/ afsci. 97267 
Brigelius-Flohé R., Traber M.G., 1999. Vitamin E: function and metabolism. FASEB J. 13, 1145-1155, https://doi. org/10.1096/fasebj.13.10.1145

Čobanová K., Faix S., Plachá I., Mihaliková K., Váradyová Z., Kišidayová S., Grešáková L., 2017. Effects of different dietary selenium sources on antioxidant status and blood phagocytic activity in sheep. Biol. Trace Elem. Res. 175, 339-346, https:// doi.org/10.1007/s12011-016-0794-0

Czauderna M., Białek M., Krajewska K.A., Ruszczyńska A., Bulska E., 2017. Selenium supplementation into diets containing carnosic acid, fish and rapeseed oils affects the chemical profile of whole blood in lambs. J. Anim. Feed Sci. 26, 192-203, https:// doi.org/10.22358/jafs/76594/2017

Czauderna M., Kowalczyk J., Krajewska K.A., 2011a. Influence of dietary selenium level on the concentration of conjugated linoleic acid isomers, other fatty acids and amino acids in the liver and femoral muscles of rats. Czech J. Anim. Sci. 56, 81-94, https:// doi.org/10.17221/55/2010-CJAS

Czauderna M., Kowalczyk J., Krajewska K.A., Rozbicka A.J., Michalski J., 2009a. Dietary selenite and conjugated linoleic acid isomers influence fatty acid concentrations in the liver and femoral muscles of rats. J. Anim. Feed Sci. 18, 564-581, https://doi.org/10.22358/jafs/66432/2009

Czauderna M., Kowalczyk J., Marounek M., 2011b. The simple and sensitive measurement of malondialdehyde in selected specimens of biological origin and some feed by reversed phase high performance liquid chromatography. J. Chromatogr. B 879 , 2251-2258, https://doi.org/10.1016/j.jchromb.2011.06.008

Czauderna M., Kowalczyk J., Niedźwiedzka K.M., 2009b. Simple HPLC analysis of tocopherols and cholesterol from specimens of animal origin. Chem. Anal. (Warsaw) 54, 203-214

Czauderna M., Kowalczyk J., Niedźwiedzka K.M., Leng L., Cobanova K., 2009c. Dietary selenized yeast and CLA isomer mixture affect fatty- and amino acid concentrations in the femoral muscles and liver of rats. J. Anim. Feed Sci. 18, 348-361, https://doi. org/10.22358/jafs/66399/2009

Czauderna M., Ruszczyńska A., Bulska A., Krajewska K.A., 2018. Seleno-compounds and carnosic acid added to diets with rapeseed and fish oils affect concentrations of selected elements and chemical composition in the liver, heart and muscles of lambs. Biol. Trace Elem. Res. 184, 378-390, https://doi.org/10.1007/s12011-017-1211-z

Czauderna M., Smogorzewska E., 1986. Studies on the incorporation of $\mathrm{Se}$ in the presence of glutathione and the distribution of $\mathrm{Zn}$, $\mathrm{Co}, \mathrm{Fe}, \mathrm{Rb}$ and $\mathrm{Cs}$ in mice by instrumental neutron activation analysis. J. Radioanal. Nucl. Chem. 97, 347-352, https://doi. org/10.1007/BF02035680

Fernández M., Ordóňez J.A., Cambero I., Santos C., Pin C., de la Hoz L., 2007. Fatty acid compositions of selected varieties of Spanish dry ham related to their nutritional implications. Food Chem. 101, 107-112, https://doi.org/10.1016/j.foodchem.2006.01.006

Gai Z., Wang T., Visentin M., Kullak-Ublick G.A., Fu X., Wang Z., 2019. Lipid accumulation and chronic kidney disease. Nutrients 11 , 722, https://doi.org/10.3390/nu11040722

Haliga R.E., Mocanu V., Badescu M., 2015. Antioxidative and antiatherogenic effects of flaxseed, a-tocopherol and their combination in diabetic hamsters fed with a high-fat diet. Exp. Ther. Med. 9, 533-538, https://doi.org/10.3892/etm.2014.2102

Haug A., Eich-Greatorex S., Bernhoft A., Wold J.P., Hetland H., Christophersen O.A., Sogn T., 2007. Effect of dietary selenium and omega-3 fatty acids on muscle composition and quality in broilers. Lipids Health Dis. 6, 29, https://doi.org/10.1186/1476511X-6-29
Ibrahim N.S., Sabic E.M., Wakwak M.M., El-Wardany I.E., El-Homosany Y.M., El-Deen Mohammad N., 2020. In-ovo and dietary supplementation of selenium nano-particles influence physiological responses, immunological status and performance of broiler chicks. J. Anim. Feed Sci. 29, 46-58, https://doi.org/10.22358/jafs/118209/2020

Infante J.P., 1986. Vitamin E and selenium participation in fatty acid desaturation. A proposal for an enzymatic function of these nutrients. Mol. Cell. Biochem. 69, 93-108, https://doi. org/10.1007/BF00224757

Juniper D.T., Phipps R.H., Ramos-Morales E., Bertin G., 2008. Effect of dietary supplementation with selenium-enriched yeast or sodium selenite on selenium tissue distribution and meat quality in beef cattle. J. Anim. Sci. 86, 3100-3109, https://doi. org/10.2527/jas.2007-0595

Krajewska K.A., Rozbicka-Wieczorek A.J., Kowalczyk J., Czauderna M., 2012. Dietary linseed oil and selenate affect the concentration of fatty acids and selenium in the spleen, pancreas, and kidneys of lambs. J. Anim. Feed Sci. 21, 285-301, https://doi.org/10.22358/jafs/66077/2012

Krajewska-Bienias K.A., Czauderna M., Marounek M., RozbickaWieczorek A.J., 2017. Diets containing selenized yeast, selenate, carnosic acid and fish oil change the content of fatty acids, tocopherols and cholesterol in the subcutaneous fat of lambs. J. Anim. Plant Sci. 27, 1781-1794

Lagarde M., Guichardant M., Bernoud-Hubac N., Calzada C., Véricel E., 2018. Oxygenation of polyunsaturated fatty acids and oxidative stress within blood platelets. Biochim. Biophys. Acta Mol. Cell Biol. Lipids 1863, 651-656, https:// doi.org/10.1016/j.bbalip.2018.03.005

Lee Y.-H., Lim W., Sung M.-K., 2018. Carnosic acid modulates increased hepatic lipogenesis and adipocytes differentiation in ovariectomized mice fed normal or high-fat diets. Nutrients 10, 1984, https://doi.org/10.3390/nu10121984

McDowell L.R., Davis P.A., Cristaldi L.A., Wilkinson N.S., Buergelt C.D., Van Alstyne R., 2005. Toxicity of selenium: Fear or precaution? Feedstuffs 77(22), 12-13

Mikulková K., Illek J., Kadek R., 2020. Glutathione redox state, glutathione peroxidase activity and selenium concentration in periparturient dairy cows, and their relation with negative energy balance. J. Anim. Feed Sci. 29, 19-26, https://doi. org/10.22358/jafs/117867/2020

Morán L., Andrés S., Blanco C., Benavides J., Martínez-Valladares M., Moloney A.P., Giráldez F.J., 2017. Effect of dietary supplementation with carnosic acid or vitamin $E$ on animal performance, hematological and immunological characteristics of artificially reared suckling lambs before and after road transport. Arch. Anim. Nutr. 71, 272-284, https://doi.org/10.1080/1 745039X.2017.1316137

Morán L., Andres S., Bodas R., Benavides J., Prieto N., Pérez V., Giráldez F.J., 2012a. Antioxidants included in the diet of fattening lambs: effects on immune response, stress, welfare and distal gut microbiota. Anim. Feed Sci. Technol. 173, 177-185, https://doi.org/10.1016/j.anifeedsci.2012.01.010

Morán L., Andrés S., Bodas R., Prieto N., Giráldez F.J., 2012b. Meat texture and antioxidant status are improved when carnosic acid is included in the diet of fattening lambs. Meat Sci. 91, 430-434, https://doi.org/10.1016/j.meatsci.2012.02.027

Morán L., Giráldez F.J., Panseri S., Aldai N., Jordán M.J., Chiesa L.M., Andrés S., 2013. Effect of dietary carnosic acid on the fatty acid profile and flavour stability of meat from fattening lambs. Food Chem. 138, 2407-2414, https://doi.org/10.1016/j. foodchem.2012.12.033 
Navarro-Alarcon M., Cabrera-Vique C., 2008. Selenium in food and the human body: a review. Sci. Total Environ. 400, 115-141, https://doi.org/10.1016/j.scitotenv.2008.06.024

NRC (National Research Council), 2007. Nutrient Requirements of Small Ruminants: Sheep, Goats, Cervids, and New World Camelids. The National Academies Press. Washington, DC (USA), https://doi.org/10.17226/11654

Rayman M.P., 2004. The use of high-selenium yeast to raise selenium status: how does it measure up? Br. J. Nutr. 92, 557-573, https://doi.org/10.1079/bjn20041251

Rozbicka-Wieczorek A.J., Krajewska-Bienias K.A., Czauderna M., 2016a. Dietary carnosic acid, selenized yeast, selenate and fish oil affected the concentration of fatty acids, tocopherols, cholesterol and aldehydes in the brains of lambs. Arch. Anim. Breed. 59, 215-226, https://doi.org/10.5194/aab-59-215-2016

Rozbicka-Wieczorek A.J., Szarpak E., Brzóska F., Śliwiński B., Kowalczyk J., Czauderna M., 2012. Dietary lycopenes, selenium compounds and fish oil affect the profile of fatty acids and oxidative stress in chicken breast muscle. J. Anim. Feed Sci. 21, 705-724, https://doi.org/10.22358/jafs/66143/2012

Rozbicka-Wieczorek A.J., Wiesyk E., Krajewska-Bienias K.A., Wereszka K., Czauderna M., 2016b. Supplementation effects of seleno-compounds, carnosic acid, and fish oil on concentrations of fatty acids, tocopherols, cholesterol, and amino acids in the livers of lambs. Turk. J. Vet. Anim. Sci. 40, 681-693, https://doi.org/10.3906/vet-1509-12

Saini V., Fatima N., Baranwal S., Ishaq F., Singh R.N., Khan A., 2012. Anti-atherogenic and anti-oxidant effect of tocopherol and tocotrienols on $\mathrm{Cu}^{++}$mediated low-density lipoprotein (LDL) oxidation in normallipidemic subjects. Eur. J. Exp. Biol. 2, 1071-1086

Salvayre R., Negre-Salvayre A., Camaré C., 2016. Oxidative theory of atherosclerosis and antioxidants. Biochimie 125, 281-296, https://doi.org/10.1016/j.biochi.2015.12.014

Schweizer U., Streckfuß F., Pelt P., Carlson B.A., Hatfield D.L., Köhrle J., Schomburg L., 2005. Hepatically derived selenoprotein $\mathrm{P}$ is a key factor for kidney but not for brain selenium supply. Biochem. J. 386, 221-226, https://doi. org/10.1042/BJ20041973

Shanu A., Groebler L., Kim H.B., Wood S., Weekley C.M., Aitken J.B., Harris H.H., Witting P.K., 2013. Selenium inhibits renal oxidation and inflammation but not acute kidney injury in an animal model of rhabdomyolysis. Antioxid. Redox Signal. 18, 756-769, https://doi.org/10.1089/ars.2012.4591
Shi X., Wang W., Zheng S., Zhang Q., Xu S., 2020. Seleno-methionine relieves inflammation in the chicken trachea caused by LPS though inhibiting the NF-kB pathway. Biol. Trace Elem. Res. 194, 525-535, https://doi.org/10.1007/s12011-019-01789-1

Strzetelski J.A., Brzóska F., Kowalski Z.M., Osięgłowski S., 2014. Feeding Recommendation for Ruminants and Feed Tables (in Polish). National Research Institute of Animal Production. Kraków (Poland), pp. 392

Suzuki K.T., 2005. Metabolomics of selenium: Se metabolites based on speciation studies. J. Health Sci. 51, 107-114, https://doi. org/10.1248/jhs.51.107

Tuoxunjiang H., Yimamu A., Li X.Q., Maimaiti R., Wang Y.L., 2020. Effect of ensiled tomato pomace on performance and antioxidant status in the peripartum dairy cow. J. Anim. Feed Sci. 29, 105-114, https://doi.org/10.22358/jafs/124049/2020

Uhliřová L., Volek Z., 2019. Effect of dehulled white lupine seeds on the milk production and milk composition in rabbit does and the growth performance of their litters before weaning. J. Anim. Feed Sci. 28, 291-297, https://doi.org/10.22358/ jafs/110371/2019

Wei C., Tan X., Liu G., Wan F., Zhao H., Zhang C., You W., Liu X., Zhang $X$., Jin Q., 2020. $\beta$-carotene as a dietary factor affecting expression of genes connected with carotenoid, vitamin A and lipid metabolism in the subcutaneous and omental adipose tissue of beef cattle. J. Anim. Feed Sci. 29, 11-18, https://doi.org/10.22358/jafs/117866/2020

Wolin M.J., 1979. The rumen fermentation: a model for microbial interactions in anaerobic ecosystems. In: M. Alexander (Editor). Advances in Microbial Ecology. Volume 3. Springer. Boston, MA (USA), pp. 49-77, https://doi.org/10.1007/978-14615-8279-3_2

Yusháu A.Z., 2018. Fatty acid profile, thrombogenic and athrogenic indices in the raw milk of cow and sheep breeds. DUJOPAS 4, 299-307

Zu K., Ip C., 2003. Synergy between selenium and vitamin E in apoptosis induction is associated with activation of distinctive initiator caspases in human prostate cancer cells. Cancer Res. 63, 6988-6995 